\title{
The Effects of Kobane in the Reconfiguration of the Popular Geopolitical Codes of Turkey's Kurdish Movement
}

\author{
Alejandro Ciordia ${ }^{1}$ \\ Department of Sociology and Social Research, University of Trento, \\ Trento, Italy \\ Correspondence address: Alejandro Ciordia, Doctoral School of Social Sciences, \\ University of Trento, via Verdi, 26 - 28122 Trento, Italy; Email: \\ a.ciordiamorandeira@unitn.it; ORCID: https://orcid.org/0000-0001-6586-924X
}

**This is the Author Accepted Manuscript (AAM) version of this article. It was accepted for publication to Turkish Studies journal on February $13^{\text {th }}, 2018$ and this final version was submitted on February $14^{\text {th }}, 2018$. Contact the author for an update on on-line and paper publication date or check the journal's homepage (https://www.tandfonline.com/toc/ftur20/current).

A possible way to reference this is:

Ciordia, Alejandro (forthcoming), "The Effects of Kobane in the Reconfiguration of the Popular Geopolitical Codes of Turkey's Kurdish Movement”, Turkish Studies.

$* * 8,946$ words

\footnotetext{
${ }^{1}$ Alejandro Ciordia is a $\mathrm{PhD}$ candidate in Sociology and Social Research at the University of Trento. He obtained a BA in Law and Political Science and a MA in Contemporary Arab and Islamic Studies (MA), both at Universidad Autónoma de Madrid (UAM). His research interests include social movements and collective action, nationalist movements, and Turkish politics, while methodologically he favours multimethod approaches, combining tools such as social network analysis and several forms of sociologicallyoriented text analyses. Currently, he is conducting research for his doctoral dissertation on the role of national identity on the relational structures of civil society organizations in the Basque Country.
} 


\title{
The Effects of Kobane in the Reconfiguration of the Popular Geopolitical Codes of Turkey's Kurdish Movement
}

\begin{abstract}
The attack carried out by Daesh against Kobane in 2014 prompted the mobilization of worldwide media attention and of large crowds protesting all over Turkey's Kurdish-majority Southeast and beyond. This paper examines the potentially transformative effects of this event on the popular geopolitical codes of the Kurdish nationalist movement in Turkey. This is done through a qualitative content analysis of 36 op-ed articles published in the newspapers Evrensel and Özgür Gündem. Three core findings stand out: (a) a constant emphasis on Turkey's alleged links with Daesh, even before Kobane; (b) a boundary deactivation with respect to the US and "the West"; and (c) a re-articulation of self-representative frames, which initially relied on post-materialistic arguments and later emphasized security and stability.
\end{abstract}

Keywords: Kurdish movement, transformative events, popular geopolitical codes, frame analysis, Kobane

\section{Introduction}

Among the multiple issues that make Turkey's politics so extremely complex, the socalled "Kurdish question" stands out as "the mother of all problems in Turkey" ${ }^{3}$. The confrontation between Turkey's security forces and the PKK (Partiya Karkerên Kurdistan, Kurdistan Workers' Party) started back in 1984, having caused more than 40.000 deaths and displaced more than three million people since then. ${ }^{4}$

It is beyond the scope of this article to present a historic account of the conflict's precedents and development, so attention is focused on the last few years. Since 2013, the Kurdish question has regained salience in the agenda, because of the hopes attached to the so-called "Solution Process" (Çözüm süreci) and also because of its interrelation with the increasingly entangled war in Syria. In this context, the offensive of the radical

2. See, among others: Barkey and Fuller, Turkey's Kurdish Question; Bilgin and Sarihan, Understanding Turkey's Kurdish Question; Ergil, "The Kurdish Question in Turkey"; Kirişci and Winrow, The Kurdish Question and Turkey; and Yeğen, "Turkish Nationalism and the Kurdish Question."

3. Çakir, "The Problem with Turkey's PKK Peace Process." Al-Monitor, November 11, 2014.

4. Despite figures sometimes vary according to different sources, this estimation is the most commonly accepted both in the academia and the press. For more detailed statistics up to 2010 see Sarihan, "The Two Periods of the PKK Conflict." 
jihadist organization Daesh ${ }^{5}$ against the Syrian-Kurdish city of Kobane ${ }^{6}$ in September 2014 represents a turning point, both for the peace process between Ankara and the PKK, as well as for the war in Syria. Focusing on the former, the four-month siege of Kobane and the succeeding victory of Syria's Kurds against Daesh could be considered as a transformative event, ${ }^{7}$ not only in the recent development of the Kurdish conflict in Turkey but more generally in the evolution of the Kurdish movement's collective action frames. Thus, the goal of this investigation is to examine the effects of this crucial episode on the geopolitical codes -that is, frames regarding international politics- of the Kurdish nationalist movement in Turkey, at the popular level. In order to assess its evolution over time, representative newspapers are used as sources of data, analyzing the geopolitical content of op-ed articles.

In the next section, a descriptive summary of the events related to the siege of Kobane is provided. Next, I present the theoretical framework of this investigation, which is basically built upon the "framing perspective" within the literature on collective action and social movements, complemented with insights from critical geopolitics. Following this, the empirical strategy employed is carefully described, with particular reference to data collection and analytic techniques. Then, the main results of the investigation are presented and discussed, before developing a tentative explanation which draws upon a process-mechanism approach. Lastly, the article concludes by underlining its potential contributions, as well as its shortcomings.

\section{The siege of Kobane from the other side of the border}

Kobane is a Syrian city situated right next to the Turkish border, more precisely on the Mürşitpınar border crossing, which is just ten kilometres away from the Turkish city of Suruç, in the province of Şanliurfa. With a population of about 400.000 people before Daesh's offensive, ${ }^{8}$ it has been the capital of one of the three cantons that form the de facto autonomous region of Rojava since July 19, 2012, when the Syrian regime's forces withdrew from the Kurdish-majority regions in the north of the country. Since then, the Kurds have formed their own institutions, in which the PYD (Partiya Yekîtiya Demokrat,

5. Self-proclaimed as "ad-Dawlah al-Islāmiyah fì 'l- 'Irāq wa-sh-Shām", translated into English either as the "Islamic State of Iraq and the Levant" or the "Islamic State of Iraq and Syria". The acronyms used to refer to the group range from ISIL, ISIS or IS, to the Arabic form Da'ish or Daesh. In this article the latter term will be used, as it "has also gained currency, both in the Middle East and further afield, and has been used as a way of challenging the legitimacy of the group due to the negative connotations of the word." See, for instance: Irshaid, "Isis, Isil, IS or Daesh?” BBC News, December 2, 2015.

6. Kobanî in Kurdish; 'Ayn al- 'Arab in Arabic. In this paper, I will use the term Kobane, as it is the most extended way of spelling in English and the Western media in general -although Kobani is also used-, presenting also the most similar pronunciation to the original Kurdish name.

${ }^{7}$ McAdam \& Sewell, "It's about time"; Sewell, "Historical events as transformations of structures."

8. According to estimations provided by UNHCR. Source: Al Jazeera English, "Kurds Flee" September 24, 2014. 
Democratic Union Party) stands as the main political actor. Actually, its armed wing made up by the the YPG (Yekîneyên Parastina Gel, People's Protection Units) and the all-women YPJ (Yekîneyên Parastina Jin, Women's Protection Units) brigades- are the official security forces of Rojava government, along with the Asayţ̧ police units.

The summer of 2014 witnessed the emergence of Daesh as a major international concern. After it split from Al-Qaeda, Daesh started making important territorial gains in Iraq, and soon after the organization declared itself a caliphate in June 29, 2014. As the Iraqi army was not able to combat Daesh, the militia forces controlled by the Kurdish Regional Government (KRG) of Northern Iraq -widely known as peshmergas- came out as the only force capable of stopping the jihadists militarily. Daesh offensive in August 2014 against the Iraqi city of Sinjar - which was defended on the ground not only by peshmergas but also by units of the YPG-YPJ and the PKK- and the subsequent massacres of Yazidi Kurds on the hands of the fundamentalist prompted US President Obama to authorize, for the first time, air strikes against Daesh, marking the beginning of an air campaign conducted by an US-led international coalition.

In Kobane, as in the two other Kurdish cantons -Jazira and Afrin- Daesh had been fighting against the YPG-YPJ for months. However, it was not until early September 2014 when the jihadists launched an offensive against the city and the surrounding canton of Kobane. Unlike previous offensives, this attack received significant media attention from the international media, probably due to Daesh's dramatic growth in the previous months. In this case, Daesh offensive in Kobane was widely portrayed as an existential threat for Kurds, the only group who had been able to stop the self-proclaimed caliphate; hence, the potential fall of Kobane was also interpreted as a serious threat for the West.

The progress of Daesh toward the city caused a massive flow of thousands of refugees, many of them aiming to protect themselves at the other side of the border. For its part, the PKK, as it had already done before, made a call to its sympathizers -in particular to "the youth of Bakûr" (North Kurdistan)- to join Kobane's resistance. Turkey decided to temporarily close the border, in contraposition with the "open gates" policy it had maintained for most part of the war in Syria, causing confrontations between hundreds of Kurds who wanted to join the resistance and the police and army units deployed at the border crossing.

On September 23, 2014, the US-led international coalition carried out the first air strikes against Daesh lines in the surroundings of Kobane, for which Turkey refused to allow the use of its military bases unless the operation targeted Al-Assad. That week, the Turkish parliament started debating on extending one more year the authorization for the government to conduct military operations in Syria if necessary. Both events prompted some optimism among Kurds, but it rapidly turned into frustration because of the insufficiency of air attacks against Daesh's advance and Turkey's passiveness.

With this critical situation on the ground and increasing calls from the pro-Kurdish HDP (Halkların Demokratik Partisi, Peoples' Democratic Party) to mobilize against the Turkish government, massive demonstrations took place in October 6, 2014, the same day that Daesh was entering the city. This was not the first episode of protests, but it was the first time that protests extended beyond the country's Southeast, taking place also in 
Western cities such as Istanbul and Ankara. These demonstrations quickly turned violent after clashes between pro-Kurdish protestors and security forces, and, in some cases, between the former and Islamist groups associated with Huda-Par, ${ }^{9}$ causing 35 deaths all over the country just in four days, and the imposition of curfews in cities such as Diyarbakır, Siirt or Van. Protests continued during October, not only in Turkey but also in some European cities, although with diminishing mobilization and intensity.

On October 20, the Turkish government announced the decision to allow the crossing of the Syrian opposition Free Syrian Army (FSA) and Iraqi peshmergas through Turkish territory in order to help Kurdish resistance in Kobane. This decision, which came after a phone call between Obama and Erdoğan, finally broke the official neutral position of Turkey in the battle, but for many Kurdish political leaders it was too little and too late.

Even though fighting in Kobane continued during the next months, the stabilization of front lines first and the gradual Kurdish recovery diminished both the levels of social confrontation in Turkey and its salience on the international political and media agenda. However, the constant trickle of dead militants and the frequent public funerals that were taking place in many Kurdish-majority cities and towns maintained this issue very present on the Turkish side of the border, even leading to renewed episodes of violence between PKK and Huda-Par sympathizers. Officially, the liberation of Kobane was achieved on January 27, 2015, but combats continued, gradually forcing the retreat of Daesh out of the canton during the following months. The YPG-YPJ advance was finally consolidated in mid-June, when the Kurdish forces took the city of Qamishlo (Tell Abyad) from Daesh, effectively establishing territorial continuity between the cantons of Jazira and Kobane.

Academic literature on the siege of Kobane is still scant due to the recent nature of the event. Within this reduced group of academic sources, one can distinguish between works that look at the siege of Kobane as an episode of the increasingly complex war in Syria, ${ }^{10}$ and others that have studied it from the perspective of Turkey's Kurdish conflict. $^{11}$

Despite the scarcity of specific academic sources on Kobane and the war in Syria, there is a considerable amount of works refering to past regional events in neighbouring countries that have influenced in one way or another the Kurdish nationalist movement in Turkey. Recently, within the context of the current war in Syria but before the surge of Daesh and the siege of Kobane, some authors had already pointed out at potentially spillover effects that the action of Syrian-Kurdish groups could have in Turkey's

9. A Kurdish Islamist party associated with the radical sunni movement Hizbullah, which does not have any relationship with the famous homonymous shia organization in Lebanon. More about this group in: Gürbüz, "Revitalization of Kurdish Islamic Sphere"

10. E.g. Álvarez-Ossorio, "Guerra de agotamiento en Siria"; and Thornton, "Problems with the Kurds as Proxies"

11. E.g. Gunes and Lowe, "The Impact of the Syrian War on Kurdish Politics"; Gunter, "Iraq, Syria, Isis and the Kurds"; Larrabee, "Turkey and the Changing Dynamics of the Kurdish Issue"; and Weiss, "From constructive engagement to renewed estrangement?" 
"Kurdish issue". ${ }^{12}$ During the previous decade, the impact of the US invasion of Iraq and the subsequent creation of the Kurdistan Regional Government (KRG) in the north of the country was thoroughly debated. ${ }^{13}$ Moreover, the influence on Turkey's Kurds of developments in Iraq have long been acknowledged and studied, particularly since the revolts led by Mustafa Barzani against Bagdad in the 1960s. ${ }^{14}$ Going even further in history, the simbolic influence of the short-lived Kurdish Republic of Mahabad in Iran in 1946 has long been recognized as well. ${ }^{15}$ Hence, it can be noted that the influence on Turkey's Kurdish nationalism of Kurdish struggles in Iran, Iraq or Syria is neither a unique nor a recent phenomenon. Furthermore, beyond the Kurdish case, there are multiple examples of significant influence of transformative events from other geopolitical contexts on third parties. This is what has been labelled as cross-national diffusion. ${ }^{16}$ This diffusion does not only refer to material and organizational tools, demands or episodes of collective action, but can also include simbolic elements such as collective identities, solidarity networks, values, and ideological or cognitive frames. ${ }^{17}$

\section{Theoretical framework: combining frames and critical geopolitics}

Nationalist movements, as a highly relevant form of collective action, are receiving increasing attention from the social movement literature. ${ }^{18}$ Nationalism could be defined in general terms as "both an ideology and a movement that aims to have a perfect one-toone correspondence between nation and state". ${ }^{19}$ Within this broad category, Kurdish nationalism could be described as an example of ethno-nationalist movements, that is, those networks of collective action that direct their efforts to reshape or exit current state structures $^{20}$ and that base their collective identity on a self-perception of cultural difference in relation to other social groups, that is, on ethnicity. ${ }^{21}$ Ethno-nationalism

12. E.g. Carpenter, "Tangled Web," 5-7; and Lawson, "Syria's Mutating Civil War"

13. Tank, "Analysis"

14. Barkey and Fuller, Turkey's Kurdish Question, 49-53; and White, Primitive Rebels Or Revolutionary Modernizers?, 129-34.

15. Gunter, "The Kurdish Problem in Turkey," 402; and McDowall, A Modern History of the Kurds, 231-48.

16. della Porta and Diani, Social Movements, 186-88.

17. McAdam, Tarrow, and Tilly, Dynamics of Contention, 333-39; and Tilly and Tarrow, Contentious Politics, 27-44.

18. For reviews, see: Muro, "Ethnicity, Nationalism, and Social Movements"; and Olzak, "Ethnic and Nationalist Social Movements." Actually, as some authors have pointed out (e.g. Tilly and Tarrow, Contentious Politics), the extended label of "social movement literature" is somewhat misleading, as the field focuses more broadly on various forms of contentious collective action, among which social movements campaigns are one particular subtype. Specifically, social movements can be seen as one particular mode of coordination of collective action (Diani, The Cement of Civil Society). Thus, henceforth, I will refer to this literature subfield with the broader term of "literature on collective action".

19. Muro, "Ethnicity, Nationalism, and Social Movements", 187.

20. Hooghe, "Nationalist Movements and Social Factors" 21.

21. Using a broad concept of ethnicity, based on the definition proposed by Eriksen (Ethnicity and Nationalism, 8), according to which, diverse features such as race, religion, region, 
should then be understood here as a synonim of "substate" or "peripheral" nationalism, ${ }^{22}$ and is used in order to emphasize the contrast with state-nationalism.

Besides the earliest pathological approaches to protests as a form of mass behavior, ${ }^{23}$ the literature on collective action has been traditionally fragmented into three main traditions, labelled schematically as structuralist, mobilizational, and cultural. ${ }^{24}$ This investigation focuses on the cultural or symbolic dimension of social movements, without forgetting, however, other elements, such as the opportunity structure or the mobilization of resources. ${ }^{25}$

The role of culture, traditionally overlooked in comparison with the other two traditions, has received increasing attention since the 1980s, in consonance with the broader "cultural turn" experienced within the social sciences since the 1980s. Culture can be broadly understood as encompassing all the domains of social reality related with shared meanings, ${ }^{26}$ or in other words, how people in society make sense of the world. ${ }^{27}$

Among all the topics that have received increased attention due to the "cultural turn", cognitive frames have probably received most of it in the last three decades. ${ }^{28}$ The concept of frames in sociology has its origins on the work of Erving Goffman, ${ }^{29}$ and thus it can be inscribed within the theoretical stream of symbolic interactionism. Goffman identified frames as mental orientations that organize perception and interpretation, a definition which was later picked up in the social movement literature, most notably by Snow and colleagues. The term "collective action frame" was coined and defined as "interpretative schemata that enables participants to locate, perceive and label occurrences." ${ }^{30}$ Framing, as a process, implies the attribution of meaning to events and

language, or a combination of two or more of them can be used as defining elements of this cultural difference.

22. "Peripheral nationalism seeks to bring about national self-determination by separating the nation from its host state". Hechter, Containing Nationalism, 70.

23. Kornhauser, Politics of Mass Society; and Smelser, Theory of Collective Behavior.

24. McAdam, McCarthy, and Zald, Comparative Perspectives on Social Movements.

25. Sharing the spirit of the synthetic perspective proposed by McAdam, McCarthy, and Zald (Ibid.), which later crystalized in the "contentious" -and contested- proposal put forward by McAdam, Tilly, and Tarrow. See McAdam, Tarrow, and Tilly, Dynamics of Contention; Tilly and Tarrow, Contentious Politics; and McAdam and Tarrow, "Introduction: Dynamics of Contention Ten Years On".

26. Goodwin and Jasper, Rethinking Social Movements; Jasper, Protest: A Cultural Introduction to Social Movements; Johnston and Klandermans, Social Movements and Culture; Ullrich, Daphi, and Baumgarten, "Protest and Culture"; Williams, "The Cultural Contexts of Collective Action."

27. "Including how we understand our own action and motives, how we signal them to others, how we understand the actions of other, and figure out who we are and who we wish to be." Jasper, Protest: A Cultural Introduction to Social Movements, p. x.

28. Benford and Snow, "Framing Processes and Social Movements," 612; Snow et al., "The Emergence, Development, and Future of the Framing Perspective," 35-36; Williams, "The Cultural Contexts of Collective Action," 93.

29. Goffman, Frame Analysis.

30. Snow et al., "Frame Alignment Processes, Micromobilization, and Movement Participation," 464. 
actions of individuals or groups, which directly affects the mobilization -or lack of it- of collective action. ${ }^{31}$ Cognitive frames, which are less stable and more volatile in comparison with other related ideational objects -such as values, ideology, or collective identities $^{32}$ - are also closely linked with other symbolic processes such as collective identity construction, ${ }^{33}$ as well as with the perception of political opportunity structures (POS). ${ }^{34}$

This interrelation between cognitive frames and POS is precisely where this paper focuses on. By introducing the concept of frame, the conceptualization of POS has moved from a structuralist and deterministic approach towards a more balanced account of the interactions between structure and agency. ${ }^{35}$ Even if this interrelation has certainly enriched the structuralist perspective, the study of perceived opportunity structures has still suffered from two main deficiencies, as McAdam ${ }^{36}$ points out. First, while many studies examine how the configuration and perception of POS condition collective action, few analyze structural opportunities -perceived and/or factual- as dependent variables, investigating how and why they vary. Second, there is a state-centered bias in terms of the scale of the opportunities which are taken into consideration, as "[social] movement scholars have, to date, grossly undervalued the impact of global political and economic processes in structuring the domestic possibilities for successful collective action." "37 This paper overcomes the first general objection, as its primary goal is to analyze how a specific event -the siege of Kobane- has affected the collective frames -which themelves include perceived POS- of Turkey's Kurdish nationalist movement. Regarding the second gap, this paper focuses on the interpretation of international POS, which offers both a more concrete and easily understandable dependent variable and a higher possibility of making original insights.

In order to incorporate an international dimension to the analysis of frames, we may need at this point to expand our scope and review other disciplines. Here is where geopolitics, an intermediate field between political geography and political science, ${ }^{38}$ can provide some useful conceptual tools, especially its "critical" perspective. Critical geopolitics is concerned with the complex interaction of pre-existing spaces and the social construction of them, that is to say, with the interplay between structure and action. Its main aim is "to analyze the changing modes of production and reproduction of global space (...), studying concrete historical human practices in which economic, political,

31. della Porta and Diani, Social Movements, 74.

32. Gamson and Meyer, "Framing Political Opportunity."

33. Melucci, Challenging Codes.

34. Which could be defined as "consistent -but not necessarily formal or permanent- dimensions of the political struggle that encourage people to engage in contentious politics." Tarrow, Power in Movement, 19-20.

35. An idea that can be summarized as follows: "Opportunities may shape or constrain movements, but movements can create opportunities as well" Gamson and Meyer, "Framing Political Opportunity," 276.

36. McAdam, "Conceptual Origins, Current Problems, Furure Directions," 34-37.

37. Ibid., 34. Italics from the original.

38. Cairo Carou, "Elementos para una geopolítica crítica," 197. 
symbolic and institutional elements are interconnected." 39 Thus, the state is obviously an important subject for the study of geopolitics, but proponents of the critical perspective also include supra-state and non-state actors in their analyses.

Among these practices, particular attention is paid to "discursive practices", 40 as geography can be conceptualized as a discourse, "claiming that geographical assumptions are culturally constructed and politically sustained."41 Critical geopolitics differentiates three types or levels of geopolitical reasoning: formal, practical, and popular. The first one produces "geopolitical models", ${ }^{2}$ while the other two engender "geopolitical codes". While practical geopolitical codes are applied by the political and military elite engaged in foreign policy decision making, popular geopolitical codes are the result of the narratives present in both mass media and mass culture. ${ }^{43}$ Five main calculations can be distinguished within a geopolitical code: ${ }^{44}$

(1) Identification of current and potential allies.

(2) Identification of current and potential enemies.

(3) Strategies to maintain current allies and nurture potential alliances.

(4) Strategies to counter enemies and emerging threats.

(5) Justifications of the former to the public and other actors.

Going back to the framing perspective, these five calculations of geopolitical codes can be easily integrated with Snow and Benford's three framing functions. These authors identify three core framing functions or tasks ${ }^{45}$ diagnostic (What is the nature of the problem and who is to be held responsible?), prognostic (What needs to be done to solve the problem?), and motivational (Why is it necessary to act at this time and in this way?). It is evident how the first two calculations of geopolitical codes play a diagnostic function, the third and fourth are esentially prognostic, while the last one performs a motivational or legitimatory function. This integration of geopolitical codes with one the most famous conceptualization of cognitive frames ${ }^{46}$ represents an opportunity to

39. Ibid., 209.

40. Dalby, Creating the Second Cold War.

41. Erşen, "Geopolitical Codes in Davutoglu's Views," 86.

42. Knowledge produced in the academia, think tanks or strategic institutes, in which ideas are systematically organized in theories Cairo Carou, "Elementos para una geopolítica crítica," 203; and Erşen, "Geopolitical Codes in Davutoglu's Views," 85.

43. Erşen, "Geopolitical Codes in Davutoglu's Views," 85.

44. Flint, Introduction to Geopolitics, 56.

45. Benford and Snow, "Framing Processes and Social Movements"; and Snow and Benford, "Ideology, Frame Resonance, and Participant Mobilization."

46. Though certainly not the only one. Among the wide array of existing operational definitions of frames, it is necessary to mention two other popular formulations. Gamson (Talking Politics), also within the literature on collective action, has theorized about frames in a slightly different way, identifying their three key frame components: injustice, agency, and identity. Entman ("Framing"), more popular in media and communication studies, distinguished four main domains of frames: problem definition, causal interpretation, moral evaluation, and treatment recommendation. However, only Snow and Benford's 
theoretically bridge two subfields -critical geopolitics and the literature on collective action within political sociology- which have until now remained practically unconnected, to the best of my knowledge. Indeed, in the remaining pages I will interchangeably use the terms "frames" and "codes".

Nonetheless, I would like to make a few additional considerations in order to adapt the concept of geopolitical codes, which was originally devised for the practical level of geopolitical discourses, to the popular level. First, since public and media discourses do not directly affect decision making processes, ${ }^{47}$ the prognostic calculations of popular geopolitical codes will usually be less explicit in comparison with discourses typical of the policy universe. In other words, it will be more likely to find general desiderata, ${ }^{48}$ speculations, and expressive moral statements, rather than concrete cost-benefit calculations and recommended strategies. Second, following the same line of reasoning, the pressumed absence of explicitly stated courses of action makes it more appropriate in our case to favor the term "legitimatory function" for the fifth and last geopolitical calculation, instead of the more customary use of "motivational function" in the framing literature. The legitimatory dimension of popular geopolitical codes is likely to be found in self-representing statements of the collectivity to which the speaker identifies, since this third framing function strongly connects with identity building, reproduction and reelaboration. ${ }^{49}$

\section{Empirical strategy, methodology, and data}

Starting from the theoretical framework presented in the previous section, this paper aims to investigate, first and foremost, whether the siege of Kobane (September 2014 - January 2015) has modified the popular geopolitical codes of the Kurdish nationalist movement in Turkey. Secondly, it also seeks to propose explicative hypotheses that account for the observed changes and continuities.

Regarding the time period covered, since the siege of Kobane, as a potentially transformative event, is the key independent variable, it requires a longitudinal design that examines the evolution of our dependent variable before, during, and after the event. Therefore, the time frame of analysis expands from the summer of 2012, when the independent administration of Rojava was proclaimed, up to March 2016, more than a year on after the victory of Kurdish forces over Daesh in Kobane, when Syrian Kurds

formulation is used in this research, as it is the only one clearly connecting with the concept of geopolitical codes.

47. Although especially media can affect decision making indirectly, as Sharp ("Publishing American Identity," 503) points out, since "elites are also socialized through this site [media] themselves and are thus inclined to write their geopolitics in such a way that they will not irresolvably challenge the common sense of their readership." Moreover, in representative democracies, the general public can influence geopolitical decision making indirectly through electoral mechanisms, at least in theory.

48. Mere predictions or recommendations that cannot be realistically implemented in the short term by the addressed actors, and therefore function more as long-term ideal aspirations.

49. della Porta and Diani, Social Movements, 79, 93-98; and Melucci, Challenging Codes. 
took another important political and symbolic step by proclaiming the creation of the Federation of Northern Syria.

As for the methodology, given that "the question of how to investigate and compare social movements' framing is still open," ${ }^{\circ 0}$ in this case I follow one of the most common methodological approaches: reconstructing the cognitive schemata of frames through text analysis ${ }^{51}$. The texts used in this study are all journalistic, as media discourse is also susceptible to be analyzed as a proxy to popular geopolitical codes, conceived above as a particular subtype of social movement frames, given that these are both created and reproduced in mass media. ${ }^{52}$ Since media is generally regarded by researchers on symbolic elements of social movements as a fairly good -even if biased and/or incomplete- reflection of public discourse, ${ }^{53}$ in this case, the two main pro-Kurdish newspapers written in Turkish - Özgür Gündem and Evrensel ${ }^{54}$ - are taken as reasonable proxies of the popular geopolitical codes present in the movement's bases of Kurdish nationalism in Turkey. Within the broad range of specific techniques available within text analysis, ${ }^{55}$ I adopt qualitative content analysis, with a multilevel approach to coding that combines both theoretically-driven categories and more specific categories inductively derived from the texts in later phases of analysis. More details on the analysis and coding procedures are provided below, but before that, let's take a look at data collection.

Following Holsti's ${ }^{56}$ three-step proposal for data selection, after completing the selection of senders, the first step, it is necessary to select a particular type of documents, in this case, op-ed articles. Op-eds are especially suitable for the purposes of this article, as their function is more interpretative than informative and "are the preferred formulation place for explicit opinions." ${ }^{57}$ However, given that op-eds tipically deal with an almost infinite variety of topics and that a number of them are published in both newspapers on daily basis, they still constitute an unmanageable body of documents to analyze for the

50. Vicari, "Measuring Collective Action Frames," 504.

51. See, for instance: Johnston, "Verification and Proof"; Lindekilde, "Discourse and Frame Analysis." As Johnston reasons, by acknowledging the "inextricable link between discourses and frames" one can find that "a window of access exists through the spoken words of particulars and written texts of social movement organizations" Johnston, "A Methodology for Frame Analysis,” 218, 221.

52. As mas media constructs geopolitical understandings that jointly derive from elites' discourses and from 'bottom-up' mass understandings. Sharp, "Publishing American Identity," 493.

53. E.g. Gamson, Talking Politics.

54. Both founded in the 1990s and with headquarters in Istanbul. Özgür Gündem (www.ozgurgundem.com), meaning "Free Agenda", has always been related to the Kurdish nationalist political movement, even being closed under charges of terrorism (Watts, Activists in Office, 59), lastly in August 16, 2016. Although publications stopped that month, its website is today still accessible outside Turkey. Evrensel (www.evrensel.net), "Universal", has usually voiced its support for Kurdish demands as well, but distinguishes from Özgür Gündem in the adoption of a more ideology-based socialist stand, and less on ethnic grounds. Evrensel is still active.

55. See, for instance: Titscher et al., Methods of Text and Discourse Analysis.

56. Holsti, Content Analysis for the Social Sciences and Humanities.

57. van Dijk, News As Discourse, 128. 
almost 4-year time frame. This leads us to the third stage, the selection of a subset of documents. In order to do so, we proceed to a non-probabilistic "quota sampling" procedure ${ }^{58}$ that combines two criteria: keywords ${ }^{59}$ and specific periods of publication. In a conscious effort to pick moments when geopolitical issues may had special salience in Turkey's pro-Kurdish media agenda, each of these periods starts with a key event regarding Kurds in Syria, and then the next ten days are also analyzed, thus producing a number of eleven-day temporal windows, presented in table 1 . In congruence with the longitudinal design of the analysis, and in order to control for different time periods, four of the events selected took place before the siege, four during it and the last four after the siege ended.

Table 1. Periods applied for the temporal quota sampling of articles

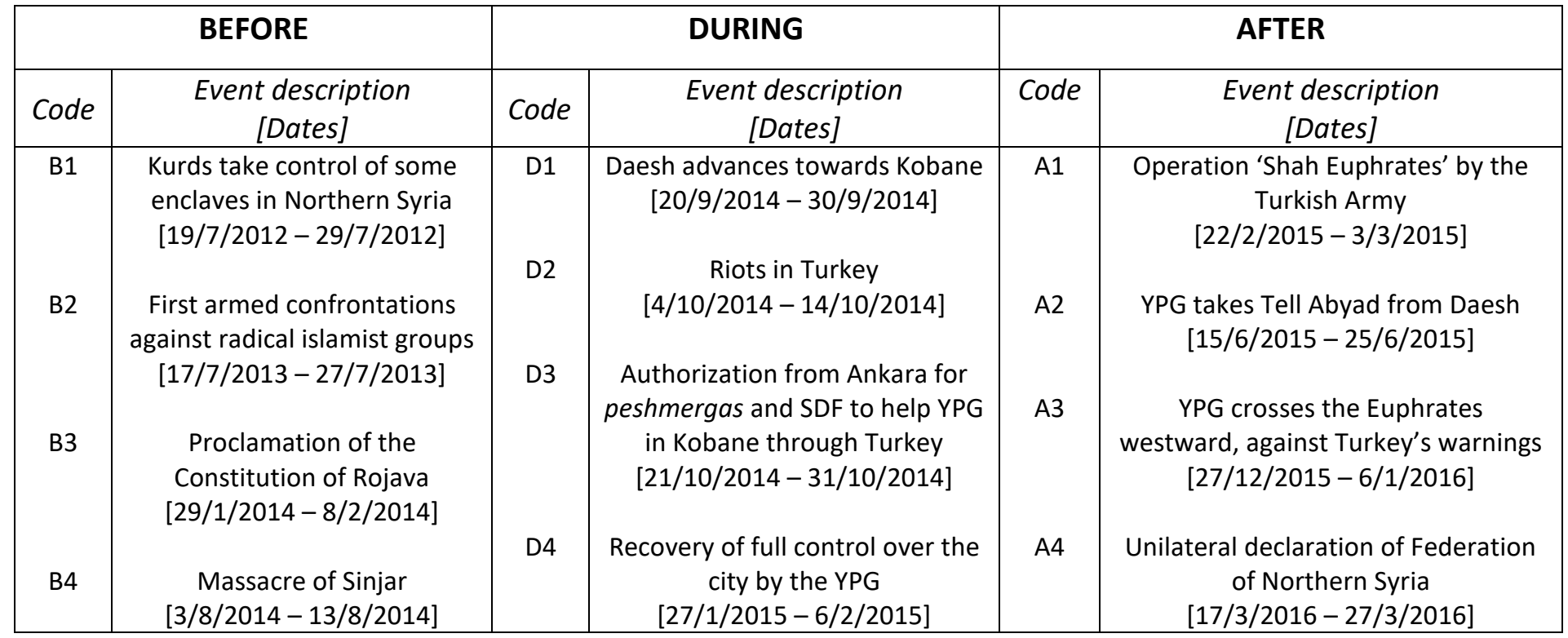

The sample resulting from the procedure described above consists of 59 op-ed articles, with quite unequal distributions throughout the three different periods, as shown in table 2. Due to the the scartcity of articles found before the siege, it was necessary to gather six more articles previous to January $2014,{ }^{60}$ thus making a final sample of 65 articles with a slightly more balanced distribution over time.

58. Titscher et al., Methods of Text and Discourse Analysis, 242.

59. In this case, we are interested in op-ed articles containing at least one of the following five terms in Turkish: diş politika (foreign policy), Suriye (Syria), DAIŞ (Daesh), Rojava, and Kobane/Kobanı (since it is spelled in both ways). Thus, the following search commands were used in Google Advanced Search:

- $\quad$ site:http://www.evrensel.net/yazi/

kobanı OR kobane OR rojava OR suriye OR daiş OR "dış politika"

- $\quad$ site:http://www.ozgur-gundem.com/yazi/

kobanı OR kobane OR rojava OR suriye OR daiş OR "dış politika"

60. To do so, the advanced search was repeated for the period between July 2012 and January 2014, but since the number of articles exceeded 100 for each newspaper, an extra requisite was introduced: keywords must appear on the title. That way the search returned six op-eds which were added to the initial sample ( $\left.\mathrm{B}^{*}\right)$. 
Table 2. Distribution of sampled articles across the different time periods

\begin{tabular}{|c|c|c|c|c|c|c|c|c|c|c|c|c|c|c|c|c|c|c|c|c|}
\hline \multicolumn{7}{|c|}{ BEFORE } & \multicolumn{6}{|c|}{ DURING } & \multicolumn{6}{|c|}{ AFTER } & \multicolumn{2}{|c|}{ TOTAL } \\
\hline $\mathrm{B}^{*}$ & B1 & B2 & B3 & B4 & Total & $\%$ & D1 & D2 & D3 & D4 & Total & $\%$ & A1 & A2 & A3 & A4 & Total & $\%$ & Total & $\%$ \\
\hline 6 & 0 & 0 & 2 & 2 & 10 & 15 & 2 & 6 & 3 & 5 & 16 & 26 & 7 & 7 & 17 & 8 & 39 & 59 & 65 & 100 \\
\hline
\end{tabular}

These 65 articles were first analyzed in order to identify false positives, classifying them according to their geopolitical relevance. Three ordinal categories were created, assigning a number to each of them in order to simplify coding: two for those articles in which geopolitical code elements have a main role; one for articles in which, despite the main topic of the article is not geopolitical, incidentally contain relevant geopolitical code information; and zero for those articles without geopolitical code information and in which the keywords appear in a casual form. Results are presented in appendix 1 and summarized in figure 1.

Figure 1. Distribution of articles over time according to geopolitical content (GC)

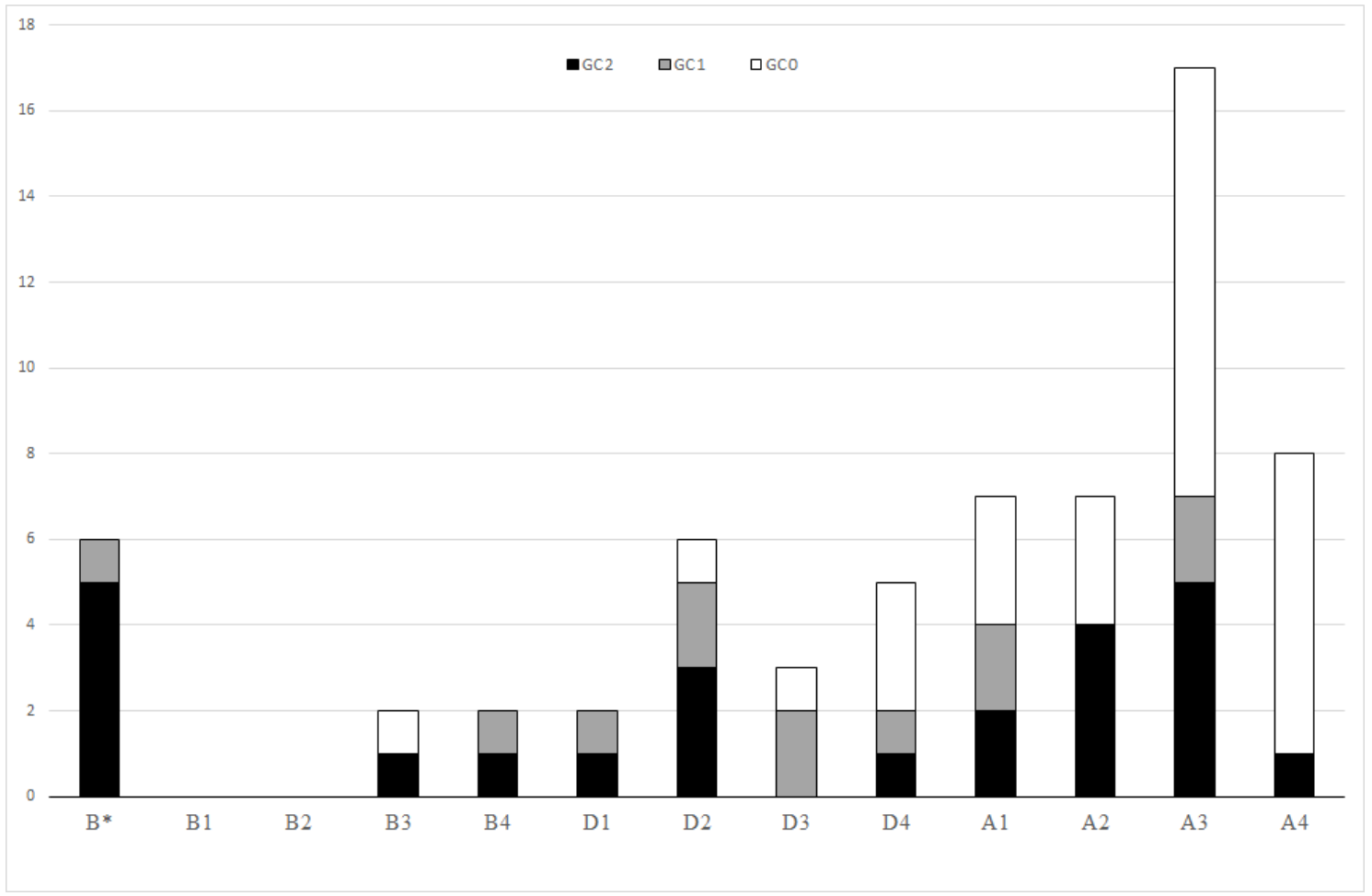

After filterring out the 29 articles without relevant geopolitical information, a deeper topical analysis was carried out only to the 36 articles coded as one or two. To do this, this investigation draws upon Van Dijk's concept of semantic macrostructure, ${ }^{61}$ which can be broadly conceptualized as an overall organization of a text in themes or topics. ${ }^{62}$ These themes or topics are also technically referred to as macropropositions, which "semantically subsume several propositions expressed in the text (possibly with

61. van Dijk, News As Discourse, 13.

62. Fairclough, Media Discourse, 13. 
the help of implicit frames or scripts). At the same time, each topic thus identified is associated with a hypothetical semantic function. "63 However, the use of these two key analytical concepts does not imply the strict application of Van Dijk's thematic analysis proposed for news within the framework of critical discourse analysis (CDA), since macropropositions -not op-ed articles ${ }^{64}$ - are used as the units of analysis in this second stage of coding. Each of the 36 articles was closely examined, reducing its geopolitical content to a few macropropositions at a high level of generalization. ${ }^{65}$ Hence, macropropositions become the individual observations -70 in total-, grouping those with similar content and semantic function within the same categories. Figure 2 summarizes the two-step codification process described above. The conceptual tree on the right side displays the complete coding scheme employed for macropropositions, which presents 14 terminal values, with their respective raw frequencies in parenthesis. ${ }^{66}$ For a more detailed acount of the 70 macropropositions identified and coded, please refer to Appendix 2.

Figure 2. Summary of the coding processes

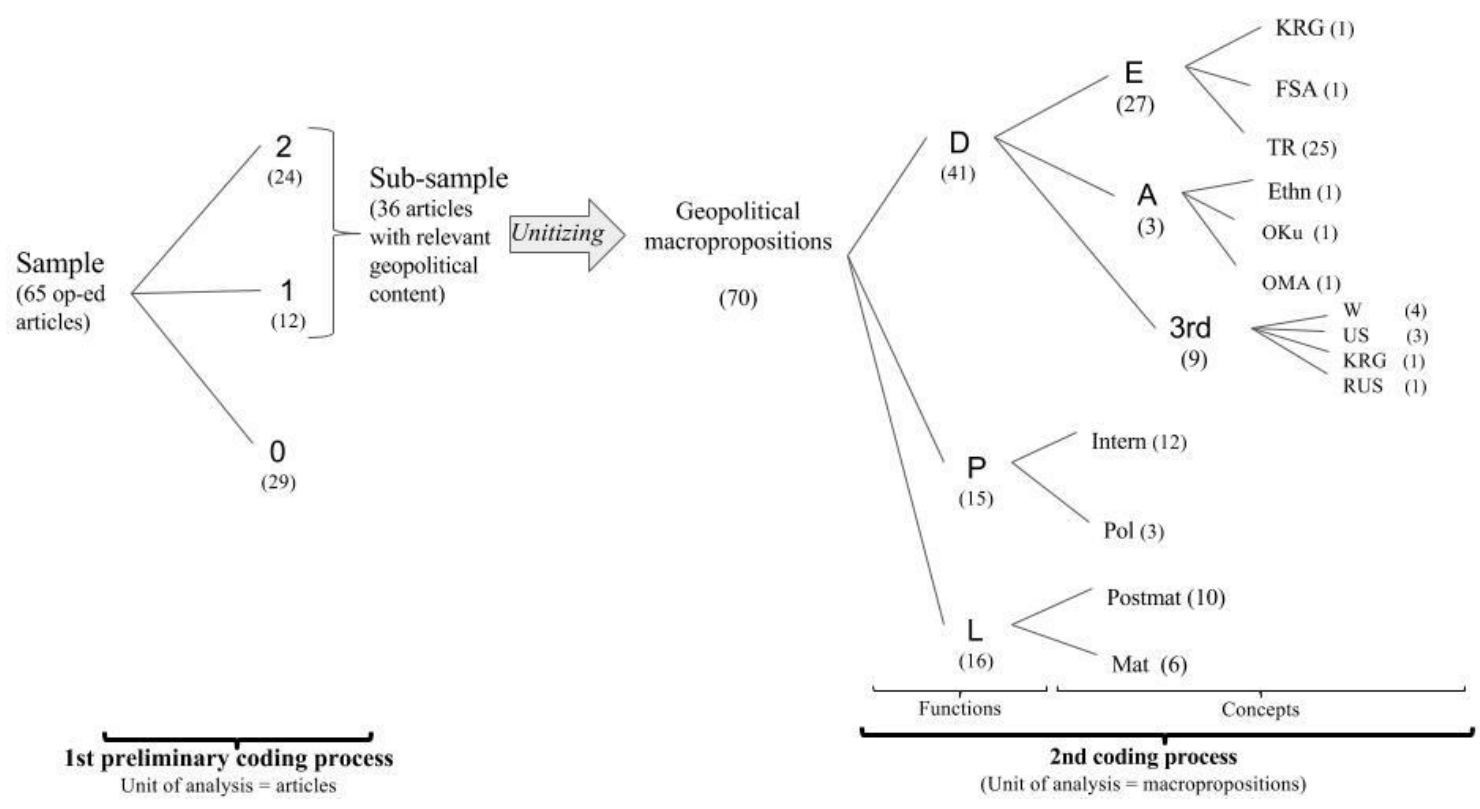

63. van Dijk, News As Discourse, 76.

64. Actually, here editorial articles function as mere units of data.

65. As each of them contain hierarchically inferior and more specific sub-themes or submacropropositions which are not examined in this investigation.

66. Inter-coder reliability (ICR) tests were conducted, comparing the author's coding output with results produced by an independent external coder. The tests conducted show reasonably high levels of reliability (79 percent agreement; Krippendorff's $\alpha=0.724$ ), surpassing customary thresholds of acceptability for tentative conclusions (Krippendorff, Content Analysis, 141-3). Given the innovative character of the coding scheme and the application of a strict criterion that treated the 14 terminal values as nominal categories, these results should be regarded as quite satisfactory. Further details on these procedures and results can be provided upon request. 


\section{Results}

Now, I proceed to describe the most significant regularities and variations in terms of macropropositons' content and frequency. For the purposes of clarity, the exposition is divided according to their semantic functions as part of popular geopolitical codes.

\section{Diagnosis: Are there friends apart from the mountains?}

Within the broad literature studying Kurdistan, the affirmation that "Kurds have no friends but the mountains", paraphrasing the title of Bulloch and Morris' book, ${ }^{67}$ has become somewhat of a cliché. Such a view portraits Kurds as an isolated population in a very hostile geopolitical environment, where enemies always outnumber allies. Assessing whether this correspond to factual reality does not fall within the objectives of this investigation, but it seems plausible that this vision might have permeated the collective frames of Kurds. The present analysis corroborates this, since 27 out of the 39 macropropositions with a diagnostic function (69 percent) refer to enemies, with just a handful of them focused on allies or third parties.

First, as it could easily be expected, Turkey is the great antagonist, ${ }^{68}$ being identified as such in all but two of all diagnostic macropropositions concerning enemies, with its presence being a constant before, during and after the siege. Actually, the diffused accusation that Turkey is allied with Daesh against Syria's Kurds is not only the result of the siege of Kobane, but was actually present in the Kurdish popular geopolitical framings well before that episode, as it can already be observed in the earliest op-eds of the sample back in 2013 (macropropositions 3, 6, 7, 12, and 14 in Appendix 2). It is particularly interesting to underscore the invariability of this diagnosis throughout the whole period, even after Turkey dramatically changed its policy about Kobane on October 20, 2014, allowing FSA units and especially peshmerga forces to military support the besieged city by crossing through Turkish territory. Therefore, it seems that this decision, which was widely interpreted abroad as a concession to Kurds, did not change even slightly the diagnostic frames of Turkey's Kurdish nationalism about Ankara with respect to the alleged dark links with Daesh. However, examining more subtle qualitative differences, it is also interesting to stress how references to Turkey as an enemy vary slightly over time, as the single attribution of blame and the almost complete identification with Daesh became hegemonic during the siege, while assessments that pointed to Turkey within a broader set of antagonists ${ }^{69}$ gradually disappeared.

67. Bulloch and Morris, No Friends but the Mountains.

68. However, some distinctions can also be made within the macropropositions that identify Turkey as a general enemy, as some focuses more on specific political parties -the governing AKP (Adalet ve Kalkınma Partisi, Justice and Development Party) and the Turkish nationalist MHP (Milliyetçi Hareket Partisi, Nationalist Movement Party)-, and others more generally on "the mainstream Turkish media".

69. The list of antagonists mentioned at some point is completed with other specific state entities -such as Syria, the KRG, Israel, Saudi Arabia or Qatar-, non-state actors -Gülen movement, the Free Syrian Army, Daesh, al-Qaeda, or the Kurdish Islamist movement of 
In contrast to enemies, mentions to allies are scarce, present in just three of the 41 diagnostic macropropositions (in particular, number 11, 53, and 61). Finally, there are other macropropositions with a clear diagnostic function but which do not clearly identify the actors mentioned neither as enemies nor allies. Thus, we could refer to them as third parties, ${ }^{70}$ a role which in this case is most often attributed to the United States in particular and to "the West" in general. Within the nine macropropositions coded as referring to third parties, seven deal with the US or the West, both during and after the siege. It is interesting to point out the evolution on the perception of the US in the sample. While in the period before the siege the US was even portrayed as an enemy, either explicitly (e.g. macroproposition 1) or implicitly as the main representative of imperialist forces (macroproposition 14), the diagnostic statements during the siege focused on three aspects: arguing why the US could never qualify as an ally, rejecting the accusations that Kurds had become lackeys (uşak) of the Western and capitalist superpower (macroproposition 27), and pointing in several occasions at the similarities in values and interests of Turkey and the US. Interestingly, during the post-Kobane period, it is not so common to observe diagnostic efforts seeking to put distance with the US, but the focus is more on how Turkey is drifting away from the West (macropropositions 42 and 47), thus implicitly emphasizing the increasing differences between the traditional Kurdish foe -Turkey- and the archetypical enemy of the Turkish and Kurdish left -the US-.

\section{Defining what to do: hopes and strategies}

The 15 macropropositions with a prognostic function present a relatively even distribution over time, being directed most of the time to Kurdish actors, finding direct prognostic interpellations to Turkey only in three occasions $(4,8$, and 33). However, this group of macropropositions is probably the most internally heterogeneous one, which make further analysis quite difficult.

\section{Legitimizing a new regional and international status for Kurds}

Macropropositions with a legitimatory function, in contrast with prognostic ones, are somewhat more homogeneous, enabling a clearer identification of patterns despite having a similar size (16 occurrences). The basic categorization that can be done is to distinguish between self-representing macropropositions ${ }^{71}$ that stress the importance of post-materialistic values (Postmat) and those that give more preeminence to materialistic ones (Mat). Drawing upon Inglehart's famous dichotomy, ${ }^{72}$ the former group of macropropositions could be operationally defined as those emphasizing the value of morally-based non-material goals such as self-expression, autonomy, freedom of speech, gender equality, or environmentalism, while the latter could be distinguished by stressing the fulfillment of material needs, such as security, sustenance and shelter.

Hizbullah- and vaguely defined groupings -such as "imperialist powers", "the West", or "colonizing forces"-.

70. Since the "relationship with those who find themselves in a neutral position" is also of great importance to the study of social movements' frames and identities. della Porta and Diani, Social Movements, 94.

71. Which of course always attach positive values to Syrian Kurds.

72. Inglehart, The Silent Revolution. 
Attending to this classification, an important variation of legitimatory macropropositions over time should be underlined. While before and during the siege the rhetoric of legitimization regarding the position of Syria's Kurds mainly refers to more abstract post-materialistic values -honor, ethnic diversity, feminism, workers' solidarity, radical democracy, or global revolution-, after February 2015 new discourses emphasizing more concrete utilitarian values -mainly stability and peace- emerged. Thus, through this change in self-representation, Kurds' own vision of the legitimacy of Kurds in Syria as a geopolitical actor has evolved from depending on pseudo-utopian ideologybased goals to embodying security and peace in the region. In other words, later selfrepresentations do not draw so much upon ideological elements -though still important and often highlighted as well- but more on the successful military performance of Kurds against Daesh.

\section{Developing a mechanistic explanation of framing processes}

Three main aspects of the evolution of popular geopolitical macropropositions can be extracted from the description made in the previous section:

(1) The constant portrayal of Turkey as the main antagonist, who is using Daesh in a proxy war against Kurds.

(2) The variable diagnostic perception of the US as a third party.

(3) The changeable rhetoric of legitimation and self-representation.

Now, we will try to make sense of these three observations, relying on the theoretical concepts formulated by the framing and the contentious politics perspectives within the literature on collective action. The main purpose is to develop tentative explicative hypotheses accounting for the findings observed above, following a processmechanism approach. ${ }^{73}$

Within the framing perspective, Benford and Snow distinguish four variable features of collective action frames to look at when comparing frames, either crosssectionally or longitudinally, namely: ${ }^{74}$ (a) problem identification and locus of attribution; (b) flexibility or rigidity; (c) interpretative scope and influence; and (d) resonance. ${ }^{75}$ These characteristics of frames can be altered, then leading to a reelaboration of frames, through the combination of three different kind of processes:

73. Following the contentious politics perspective, we conceive processes as composed by smaller-scale mechanisms. From this point of view, "mechanisms are events that produce the same immediate effects over a wide range of circumstances", while "processes assemble mechanisms into combinations and sequences that produce larger-scale effects than any particular mechanism causes by itself'. Tilly and Tarrow, Contentious Politics, 214.

74. Benford and Snow, "Framing Processes and Social Movements," 618-22.

75. Resonance can be succinctly defined as "effectiveness or mobilizing potency of proffered framings". Ibid., 619. 
discursive, strategic and contested. ${ }^{76}$ Given that this study has adopted since the outset an event-initiated perspective rather than an agent-initiated approach regarding the study of frames' variation, ${ }^{77}$ and, especially, because our focus is on the popular level of discourse rather than on identifiable specific actors' rationale for decision-making, we restrict our attention to discursive framing processes. Two specific and mutually interactive subprocesses can be identified within discursive framing: frame articulation ${ }^{78}$ and frame amplification, ${ }^{79}$ which can respectively transform features $(a)$ and $(d)$ of collective action frames. ${ }^{80}$ Apart from interpreting our three main observations in terms of frame articulation or frame amplification processes and assessing their impact on the reelaboration of the type of frames in which we are interested in this study -popular geopolitical codes-, we will also try to infer some specific mechanisms that may account for these processes, which do not come from the texts themselves but from their broader historical-political context.

Regarding the diagnostic macropropositions on Turkey as an enemy, their invariability makes us discard any transformative process of frame articulation, as there is no significant change in the representation of Turkey as the main antagonist, allied with Daesh and other radical Islamist organizations against Kurds. The regularity of this adversarial frame within Kurdish nationalism could be derived from the weight of the long history of the conflict, particularly the distrust generated by the failed "Kurdish Opening" initiative for conflict resolution initiated in $2009 .{ }^{81}$ This invariability also shows that despite high levels of support to the latest peace process among Kurds, ${ }^{82}$ boundary de-activation ${ }^{83}$ did not take place at the discursive level. This is consistent with recent explorations of conflict frames, which show how the prevalent "Kurdish master narrative" combines the maintenance of extremely antagonistic views towards the Turkish state with support of a politically negotiated solution to the conflict. ${ }^{84}$ This apparent paradox points out to the fact that even if negotiated conflict-resolution initiatives seem to have gained increasing levels of support among varied segments of Turkish society, the Kurdish movement among them, this might be the result of the general recognition of the costly military stalemate, ${ }^{85}$ rather than ethnic boundary deactivation.

76. Ibid., 623-27.

77. Snow, "Framing Processes, Ideologies and Discursive Fields," 393-94.

78. "Frame articulation involves the connection and alignment of events and experiences so that they hand together in a relatively unified and compelling fashion." Benford and Snow, "Framing Processes and Social Movements," 623.

79. "The frame amplification process involves accenting and highlighting some issues, events, or beliefs as being more salient than others" Ibid.

80. Features (b) and (c) can also vary, but through strategic and/or contested processes.

81. Pusane, "Turkey's Kurdish Opening"

82. Ünal, "Is it ripe yet?", 108-9.

83. "Decrease in the salience of the us-them distinction separating two political actors." Tilly and Tarrow, Contentious Politics, 215.

84. Uluğ and Cohrs, "An exploration of lay people's Kurdish conflict frames in Turkey", 115-6. 85. Ünal, "Is it ripe yet?" 
However, we can still observe a subtle frame amplification process, as this already-articulated frame increased its relative degree of resonance during and after the siege of Kobane. This event presented a scenario of injustice in which the Turkish government appeared as impassible, potentially capable of stopping it but unwilling to do so. The amplification process was possible through the "attribution of similarity" mechanism, which refers to the identification of two political actors as falling within the same category. ${ }^{86}$ In this case, it took place twice, through both the assimilation of an external actor -Syria's Kurds- as $u s$, as well as in the assimilation of two enemies -Daesh and Turkey- as constituting a unified other ${ }^{87}$ These may have favored, along with other factors, the interrelated processes of mobilization, escalation, polarization, and radicalization that have been observed in the context of the Kurdish question in Turkey from the autumn of 2014 onwards.

Regarding the macropropositions evaluating the role of the US, the exact opposite process can be observed, which may be referred to as frame minimization. ${ }^{88}$ Again, in this case, we do not find a changing frame articulation process, as we do not see a clear boundary shift -the US passing from an antagonist to an ally-, but actually the American superpower remains in an undefined position as a third party. The change takes place in terms of resonance, but in the opposite direction than in the previous case: instead of increasing its salience, this issue becomes more secondary as time goes by. The interplay of three concrete mechanisms may account for this process. In particular, the combination of certification $^{89}$ from the US -and other Western countries as well- to the YPG-YPJ as a reliable strategic military partner and increasing signs of decertification from Washington towards Ankara regarding the policy that should be followed in Syria, may have led to a final result of boundary deactivation. We are referring here to the ideological boundary between the traditional Kurdish nationalist ideology in Turkey, mainly based upon socialist and anti-imperialist paradigms, ${ }^{90}$ and the US and what it used to represent, from this point of view, as the head of capitalism and Western imperialism. This can be seen in the very few mentions to terms such as emperyalist (imperialist) or sömürgeci (colonialist) after the siege started, not only in the macropropositions, but throughout the entire articles.

Lastly, regarding the gradual growth of materialistic values in detriment of postmaterialistic ones in legitimatory macropropositions, we find this time a change in frame articulation, as new content emerges. With the beginning of the siege, Kurds' selfrepresentations started to be linked to the provision of security and peace, displacing the

86. Tilly and Tarrow, Contentious Politics, 215.

87. The association of Turkey and other enemies with radical Islamist positions is also a constant throughout the time period covered. This resonates well with hegemonic Western discourses against "radical Islamist terrorism", which might have made the ideological boundary deactivation towards the US somewhat easier.

88. Lavine et al., "When saying less is something new"

89. "An external authority's signal of its readiness to recognize and support the existence and claims of a political actor." Tilly and Tarrow, Contentious Politics, 215.

90. Watts, Activists in Office, 34-43; and White, Primitive Rebels Or Revolutionary Modernizers?, 129-61. 
previously hegemonic emphasis on future prospects of participatory democracy, justice, or gender equality. This change in the configuration of arguments, which arguably amounts to a frame (re)articulation process, could be read as a result of the aforementioned external certification from Western powers to Syria's Kurds. This external certification, both a cause and a result of the increased hard power of the PYD as a non-state regional power, is the clearest exponent of a more favorable politicalmilitary context for Syria's Kurds in the post-Kobane scenario. This expanded political opportunity structure (POS) provided empirical resonance ${ }^{91}$ for this kind of materialistic arguments, which were not even formulated before, as they would not have been perceived as credible by the receiving audience. This type of frame re-articulation process can be nicely summarized by Benford and Snow's observation that in some cases "changes in material conditions led to changes in frame resonance, which in turn led to reframing." 92

\section{Conclusion}

The longitudinal examination through frame analysis of popular geopolitical discourses of Kurdish nationalism in Turkey conducted in this paper has revealed three main findings:

- The constant portrayal of Turkey as the main antagonist throughout time, allegedly using Daesh in a proxy war against Kurds.

- The ideological boundary deactivation observed in the diagnostic perception of the US and the West as relevant third geopolitical actors.

- The change in the articulation of self-representation from more ethereal postmaterialistic values to more traditional materialistic arguments associated mainly with security and stability.

These three observations provide modest evidence to the main hypothesis structuring this investigation: the transformative character of the siege of Kobane for the popular geopolitical codes of Kurdish nationalism in Turkey. The absence of radical discursive ruptures before and after the event prevents us to speak of the kind of dramatic changes -both sudden and deep- that the theoretical concept of transformative events

requires. ${ }^{93}$ Nonetheless, the more subtle changes unveiled by this empirical study could be relevant in the mid- to long-term for the Kurdish nationalist movement in Turkey, since frames do not only affect perceptions of political opportunity, but also influence

91. "The apparent fit between the framings and events in the world". Benford and Snow, "Framing Processes and Social Movements," 620.

92. Ibid., 628.

93. Sewell, "Historical Events as Transformations of Structures." 
processes of collective identity formation, formulation of demands, and mobilization of collective action. ${ }^{94}$

However, two limitations should be mentioned, as they might suggest potential future lines of research. First, the relatively surprising finding that diagnostic frames portraying Turkey as an ally of foreign jihadist groups were in place well before Kobane brings up a second question: when and why did this frame emerge within the Kurdish nationalist movement? This enquiry could drive another complementary research project using a longer time frame extending further back in time. Second, while this paper has unveiled some short-term effects of Kobane on specific discursive aspects of the Kurdish nationalist movement, it is true that an empirical assessment of other kinds of consequences for Kurdish collective action in Turkey would need a longer historical perspective with respect to the event at hand. Both the limited scope of the object study popular geopolitical codes- and the temporal proximity to the event of interest are clear limitations of this paper, which nevertheless could be overcome by future socio-historical research on these ongoing turbulent times for the region.

Despite its limitations, this paper makes two main original contributions. The first one being the novel theoretical connection between the concept of collective action frames and geopolitical codes, which bridges two previously scarcely connected fields such as geopolitics and studies of collective action and social movements. The second contribution is methodological, as the systematic and transparent qualitative content analysis conducted here can be easily reproduced, stimulating other researchers to apply this accessible ${ }^{95}$ methodology, and even the coding scheme devised here, to this or other similar research topics.

94. Benford and Snow, "Framing Processes and Social Movements"; Johnston, "Verification and Proof in Frame and Discourse Analysis"; and Snow, "Framing Processes, Ideologies and Discursive Fields."

95. In the sense that no previous advanced linguistic knowledge is required, following the spirit of Titscher et al (Methods of Text and Discourse Analysis, 5-19) and Fairclough (Analysing Discourse, 1-16). 


\section{Acknowledgments}

This article derives from an initial research conducted back in 2016 for the final dissertation of the M.A. in Contemporary Arab and Islamic Studies (MEAIC) at Universidad Autónoma de Madrid (UAM), for which I received a generous grant by UAM (Ayudas para el fomento de la investigación en estudios de master - UAM 2015). I would like to express my gratitude to the program's faculty for everything I learnt that year, in particular to my tutor, Carmen Rodriguez López. Her suggestions to connect my initially blurry ideas not only with the literature on collective action but also with geopolitics positively influenced the successful development of the research project, along with her encouragement and constructive feedback. This research also benefited from suggestions received upon its presentation at two conferences in Lisbon (February 2017) and Santiago de Compostela (September 2017). I would like to thank all participants who commented on those earlier versions, as well as Isabel David and Kumru F. Toktamıs -conveners of the Lisbon conference on Turkish Politics- for believing in the paper's potential for publication. I would also like to acknowledge the very constructive comments provided by an anonymous reviewer, which clearly contributed to the improvement of this article. Last, but not least, I want to thank Daniel Rosselló, Özcan Çetin, and Tülay Y1lmaz for their generous help with different aspects of the inter-coder reliability tests conducted.

\section{Disclosure statement}

No potential conflict of interest was reported by the author. 


\section{Bibliography}

Al Jazeera English. "Kurds Flee as Clashes Rage in Northern Syria." Al Jazeera English, September 24, 2014.

http://www.aljazeera.com/news/middleeast/2014/09/syria-kurds-kobane201492410309256379.html.

Álvarez-Ossorio, Ignacio. "Guerra de agotamiento en Siria.” Politica Exterior 164 (2015): 2-12.

Barkey, Henri J., and Graham E. Fuller. Turkey's Kurdish Question. Lanham, Md.: Rowman \& Littlefield, 1998.

Benford, Robert B., and David A. Snow. "Framing Processes and Social Movements: An Overview and Assessment." Annual Review of Sociology 26, no. 1 (2000): 611-39. doi:10.1146/annurev.soc.26.1.611.

Bilgin, Fevzi, and Ali Sarihan, eds. Understanding Turkey's Kurdish Question. London: Lexington Books, 2013.

Bulloch, J, and H Morris. No Friends but the Mountains: The Tragic History of the Kurds. London: Viking, 1992.

Cairo Carou, Heriberto. "Elementos para una geopolítica crítica: tradición y cambio en una disciplina maldita." Ería 0, no. 32 (1993): 195-213. doi:10.17811/er.0.1993.195-213.

Çakir, Rusen. "The Problem with Turkey's PKK Peace Process.” Al-Monitor, November 11, 2014. http://www.al-monitor.com/pulse/politics/2014/11/turkeykurds-solution-process-pkk.html.

Carpenter, Ted Galen. "Tangled Web: The Syrian Civil War and Its Implications." Mediterranean Quarterly 24, no. 1 (December 21, 2013): 1-11. doi:10.1215/10474552-2018988.

Dalby, Simon. Creating the Second Cold War: The Discourse of Politics. London: Pinter, 1990.

della Porta, Donatella, and Mario Diani. Social Movements: An Introduction. 2nd ed. Oxford: Blackwell Publishing, 2006.

Diani, Mario. The Cement of Civil Society. Cambridge: Cambridge University Press, 2015.

Entman, Robert M. "Framing: Toward Clarification of a Fractured Paradigm.” Journal of Communication 43, no. 4 (December 1, 1993): 51-58. doi:10.1111/j.14602466.1993.tb01304.x.

Ergil, Dogu. “The Kurdish Question in Turkey.” Journal of Democracy 11, no. 3 (July 1, 2000): 122-35. doi:10.1353/jod.2000.0054.

Eriksen, Thomas Hylland. Ethnicity and Nationalism: Anthropological Perspectives. 2nd ed. Sterling, Va: Pluto Press, 2002.

Erşen, Emre. "Geopolitical Codes in Davutoglu's Views toward the Middle East." Insight Turkey 16, no. 1 (2014): 85-101.

Fairclough, Norman. Analysing Discourse: Textual Analysis for Social Research. New York: Routledge, 2003. Media Discourse. London: Arnold, 1995.

Flint, Colin. Introduction to Geopolitics. 1st ed. Abingdon: Routledge, 2006.

Gamson, William A. Talking Politics. Cambridge University Press, 1992.

Gamson, William A., and David S. Meyer. "Framing Political Opportunity." In Comparative Perspectives on Social Movements, edited by Doug McAdam, John D. McCarthy, and Mayer N. Zald, 275-90. Cambridge: Cambridge University Press, 1996. 
Goffman, Erving. Frame Analysis: An Essay on the Organization of Experience. Cambridge, MA, US: Harvard University Press, 1974.

Goodwin, Jeff, and James M. Jasper, eds. Rethinking Social Movements: Structure, Meaning, and Emotion. Lanham, Maryland: Rowman \& Littlefield Publishers, 2004.

Gunes, Cengiz, and Robert Lowe. "The Impact of the Syrian War on Kurdish Politics Across the Middle East." Chatham House, 2015. https://www.chathamhouse.org//node/18205.

Gunter, Michael M. "Iraq, Syria, Isis and the Kurds: Geostrategic Concerns for the U.S. and Turkey." Middle East Policy 22, no. 1 (March 1, 2015): 102-11. doi:10.1111/mepo.12116. . "The Kurdish Problem in Turkey." Middle East Journal 42, no. 3 (1988): 389406.

Gürbüz, Mustafa. "Revitalization of Kurdish Islamic Sphere and Revival of Hizbullah in Turkey." In Understanding Turkey's Kurdish Question, edited by Fevzi Bilgin and Ali Sarihan, 167-78. Plymouth: Lexington Books, 2013.

Hechter, Michael. Containing Nationalism. Oxford: Oxford University Press, 2000.

Holsti, Ole R. Content Analysis for the Social Sciences and Humanities. Reading, Mass.: Addison-Wesley, 1969.

Hooghe, Liesbet. "Nationalist Movements and Social Factors: A Theoretical Perspective." In The Social Origins of Nationalist Movements, 21-44. London: Sage, 1992.

Inglehart, Ronald. The Silent Revolution: Changing Values and Political Styles Among Western Publics. Princeton, N.J.: Princeton University Press, 1977.

Irshaid, Faisal. "Isis, Isil, IS or Daesh? One Group, Many Names." BBC News, December 2, 2015, sec. Middle East. http://www.bbc.com/news/world-middleeast-27994277.

Jasper, James M. Protest: A Cultural Introduction to Social Movements. Cambridge: Polity Press, 2014.

Johnston, Hank. "Verification and Proof in Frame and Discourse Analysis." In Methods of Social Movement Research, edited by Bert Klandermans and Suzanne Staggenborg, 62-91. Minneapolis, Minn.: University of Minnesota Press, 2002.

Johnston, Hank, and Bert Klandermans, eds. Social Movements and Culture. London: UCL Press, 1995.

Kirişci, Kemal, and Gareth M. Winrow. The Kurdish Question and Turkey: An Example of a Trans-State Ethnic Conflict. London: Psychology Press, 1997.

Kornhauser, William. Politics of Mass Society. Glencoe, Illinois: Free Press of Glencoe, 1959.

Krippendorff, Klaus. Content Analysis: An Introduction to Its Methodology. 2nd ed. London: SAGE, 2004.

Larrabee, F. Stephen. "Turkey and the Changing Dynamics of the Kurdish Issue." Survival 58, no. 2 (March 3, 2016): 67-73. doi:10.1080/00396338.2016.1161900.

Lavine, Marc, J. Adam Cobb, and Christopher J. Roussin. "When Saying Less Is Something New: Social Movements and Frame-Contraction Processes." Mobilization: An International Quarterly 22, no. 3 (September 1, 2017): 27592. https://doi.org/10.17813/1086-671X-20-3-275.

Lawson, Fred H. "Syria's Mutating Civil War and Its Impact on Turkey, Iraq and Iran." International Affairs 90, no. 6 (November 1, 2014): 1351-65. doi:10.1111/14682346.12173. 
Lindekilde, Lasse. "Discourse and Frame Analysis: In-Depth Analysis of Qualitative Data in Social Movement Research." In Methodological Practices in Social Movement Reseach, edited by Donatella della Porta, 195-227. Oxford: Oxford University Press, 2014.

McAdam, Doug. "Conceptual Origins, Current Problems, Furure Directions." In Comparative Perspectives on Social Movements, edited by Doug McAdam, John D. McCarthy, and Mayer N. Zald, 23-40. Cambridge: Cambridge University Press, 1996.

McAdam, Doug, John D. McCarthy, and Mayer N. Zald, eds. Comparative Perspectives on Social Movements: Political Opportunities, Mobilizing Structures, and Cultural Framings. Cambridge: Cambridge University Press, 1996.

McAdam, Doug, and William H. Sewell. "It's About Time: Temporality in the Study of Social Movements and Revolutions." In Silence and Voice in the Study of Contentious Politics, edited by Ronald Aminzade, 89-125. Cambridge: Cambridge University Press, 2001.

McAdam, Doug, and Sidney Tarrow. "Introduction: Dynamics of Contention Ten Years On." Mobilization: An International Quarterly 16, no. 1 (February 1, 2011): 110. doi:10.17813/maiq.16.1.61m83k7n14813365.

McAdam, Doug, Sidney Tarrow, and Charles Tilly. Dynamics of Contention. Cambridge University Press, 2001.

McDowall, David. A Modern History of the Kurds: Third Edition. 3rd ed. London: I.B.Tauris, 2004.

Melucci, Alberto. Challenging Codes: Collective Action in the Information Age. Cambridge: Cambridge University Press, 1996.

Muro, Diego. "Ethnicity, Nationalism, and Social Movements." In The Oxford Handbook of Social Movements, edited by Donatella della Porta and Mario Diani, 185-99. Oxford: Oxford University Press, 2015.

Olzak, Susan. "Ethnic and Nationalist Social Movements." In The Blackwell Companion to Social Movements, edited by David A. Snow, Sarah A. Soule, and Hanspeter Kriesi, 663-93. Oxford: Blackwell Publishing, 2004.

Pusane, Özlem Kayhan. “Turkey's Kurdish Opening: Long Awaited Achievements and Failed Expectations." Turkish Studies 15, no. 1 (January 2, 2014): 81-99. https://doi.org/10.1080/14683849.2014.891348.

Sarihan, Ali. "The Two Periods of the PKK Conflict: 1984-1999 and 2004-2010." In Understanding Turkey's Kurdish Question, edited by Fevzi Bilgin and Ali Sarihan, 89-102. London: Lexington Books, 2013.

Sewell, William H. "Historical Events as Transformations of Structures: Inventing Revolution at the Bastille." Theory and Society 25, no. 6 (1996): 841-81. doi:10.1007/BF00159818.

Sharp, Joanne P. "Publishing American Identity: Popular Geopolitics, Myth and The Reader's Digest." Political Geography 12, no. 6 (November 1, 1993): 491-503. doi:10.1016/0962-6298(93)90001-N.

Smelser, Neil J. Theory of Collective Behavior. New York: Free Press, 1963.

Snow, David A. "Framing Processes, Ideologies and Discursive Fields." In The Blackwell Companion to Social Movements, edited by David A. Snow, Sarah A. Soule, and Hanspeter Kriesi, 380-412. Oxford: Blackwell Publishing, 2004.

Snow, David A., and Robert D. Benford. "Ideology, Frame Resonance, and Participant Mobilization." International Social Movement Research: From Structure to Action 1, no. 1 (1988): 197-217. 
Snow, David A., E. Burke Rochford, Steven K. Worden, and Robert D. Benford. "Frame Alignment Processes, Micromobilization, and Movement Participation." American Sociological Review 51, no. 4 (1986): 464-81. doi:10.2307/2095581.

Snow, David, Robert Benford, Holly McCammon, Lyndi Hewitt, and Scott Fitzgerald. "The Emergence, Development, and Future of the Framing Perspective: 25+ Years Since 'Frame Alignment." Mobilization: An International Quarterly 19, no. 1 (February 1, 2014): 23-46. doi:10.17813/maiq.19.1.x74278226830m691.

Tank, Pinar. "Analysis: The Effects of the Iraq War on the Kurdish Issue in Turkey." Conflict, Security \& Development 5, no. 1 (April 1, 2005): 69-86. doi:10.1080/14678800500103309.

Tarrow, Sidney. Power in Movement: Social Movements and Contentious Politics. 2nd ed. Cambridge: Cambridge University Press, 1998.

Thornton, Rod. "Problems with the Kurds as Proxies against Islamic State: Insights from the Siege of Kobane." Small Wars \& Insurgencies 26, no. 6 (November 2, 2015): 865-85. doi:10.1080/09592318.2015.1095844.

Tilly, Charles, and Sidney G. Tarrow. Contentious Politics. 1st ed. Oxford: Oxford University Press, 2007.

Titscher, Stefan, Michael Meyer, Ruth Wodak, and Eva Vetter. Methods of Text and Discourse Analysis: In Search of Meaning. SAGE, 2000.

Ullrich, Peter, Priska Daphi, and Britta Baumgarten. "Protest and Culture: Concepts and Approaches in Social Movement Research - An Introduction." In Conceptualizing Culture in Social Movement Research, edited by Britta Baumgarten, Priska Daphi, and Peter Ullrich, 1-22. Basignstoke: Palgrave Macmillan, 2014.

van Dijk, Teun A. News As Discourse. London: Routledge, 1988.

Uluğ, Özden Melis, and J. Christopher Cohrs. "An Exploration of Lay People's Kurdish Conflict Frames in Turkey." Peace and Conflict: Journal of Peace Psychology 22, no. 2 (2016): 109-19. https://doi.org/10.1037/pac0000165.

Ünal, Mustafa Coşar. "Is It Ripe yet? Resolving Turkey's 30 Years of Conflict with the PKK.” Turkish Studies 17, no. 1 (January 2, 2016): 91-125. https://doi.org/10.1080/14683849.2015.1124020.

Vicari, Stefania. "Measuring Collective Action Frames: A Linguistic Approach to Frame Analysis." Poetics 38, no. 5 (October 1, 2010): 504-25. doi:10.1016/j.poetic.2010.07.002.

Watts, Nicole F. Activists in Office: Kurdish Politics and Protest in Turkey. Seattle: University of Washington Press, 2010.

Weiss, Matthew. "From Constructive Engagement to Renewed Estrangement? Securitization and Turkey's Deteriorating Relations with Its Kurdish Minority." Turkish Studies 17, no. 4 (October 1, 2016): 567-98. https://doi.org/10.1080/14683849.2016.1228456.

White, Paul J. Primitive Rebels Or Revolutionary Modernizers?: The Kurdish National Movement in Turkey. New York: Zed Books, 2000.

Williams, Rhys H. "The Cultural Contexts of Collective Action: Constraints, Opportunities, and the Symbolic Life of Social Movements." In The Blackwell Companion to Social Movements, edited by David A. Snow, Sarah A. Soule, and Hanspeter Kriesi, 91-115. Malden, MA: Blackwell Publishing, 2004.

Yeğen, Mesut. "Turkish Nationalism and the Kurdish Question.” Ethnic and Racial Studies 30, no. 1 (January 1, 2007): 119-51. doi:10.1080/01419870601006603. 
APPENDICES

\section{Appendix 1: Full sample of op-ed articles}

\begin{tabular}{|c|c|c|c|c|c|c|c|}
\hline 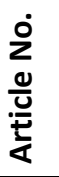 & $\begin{array}{l}\frac{1}{0} \\
\frac{0}{0} \\
\frac{0}{0} \\
\sum_{0}^{0} \\
z \\
z\end{array}$ & Date & $\frac{\text { 은 }}{2}$ & Title & Author & URL & GC \\
\hline 1 & Ev & $25 / 05 / 2013$ & $\mathrm{~B}^{*}$ & $\begin{array}{l}\text { Rojava-Hewler } \\
\text { geriliminin perde } \\
\text { arkası }\end{array}$ & Yusuf KARATAŞ & $\begin{array}{c}\text { https://www.evrensel.net/yazi/57625/rojava-hewler- } \\
\text { eriliminin-perde-arkasi }\end{array}$ & 2 \\
\hline 2 & Ev & $24 / 07 / 2013$ & $\mathrm{~B}^{*}$ & $\begin{array}{l}\text { Rojava'ya } \\
\text { müdahale }\end{array}$ & Kamil Tekin SÜREK & $\begin{array}{c}\text { https://www.evrensel.net/yazi/62977/rojavaya- } \\
\text { mudahale }\end{array}$ & 2 \\
\hline 3 & OG & 09/08/2013 & $\mathrm{B}^{*}$ & $\begin{array}{l}\text { Rusya'nın kritik } \\
\text { Rojava } \\
\text { açıklamaları... }\end{array}$ & Rahmi YAĞMUR & $\frac{\text { http://www.ozgur-gundem.com/yazi/80413/rusyanin- }}{\text { kritik-rojava-aciklamalari }}$ & 2 \\
\hline 4 & OG & $14 / 09 / 2013$ & $\mathrm{~B}^{*}$ & $\begin{array}{c}\text { Rojava ve kadın } \\
\text { devrimi }\end{array}$ & $\begin{array}{l}\text { Kadının } \\
\text { Kaleminden }\end{array}$ & $\frac{\text { http://www.ozgur-gundem.com/vazi/83620/rojava-ve- }}{\text { kadin-devrimi }}$ & 2 \\
\hline 5 & Ev & $25 / 12 / 2013$ & $\mathrm{~B}^{*}$ & $\begin{array}{l}\text { Kürtler } \\
\text { 'Rojava'yı' } \\
\text { bekliyor... }\end{array}$ & Fehim IŞIK & $\frac{\text { https://www.evrensel.net/yazi/70149/kurtler-rojavayi- }}{\underline{\text { bekliyor }}}$ & 1 \\
\hline 6 & Ev & $15 / 01 / 2014$ & $\mathrm{~B}^{*}$ & $\begin{array}{c}\text { El Kaide-iHH } \\
\text { operasyonu ve } \\
\text { hükümetin } \\
\text { Suriye manevrası }\end{array}$ & İhsan ÇARALAN & $\frac{\text { https://www.evrensel.net/yazi/70338/el-kaide-ihh- }}{\text { operasyonu-ve-hukumetin-suriye-manevrasi }}$ & 2 \\
\hline 7 & OG & $01 / 02 / 2014$ & B3 & Devrim yapmak & Figen YÜKSEKDAĞ & $\begin{array}{c}\frac{\text { http://www.ozgur-gundem.com/yazi/96754/devrim- }}{\text { yapmak }} \\
\end{array}$ & 2 \\
\hline 8 & Ev & $08 / 02 / 2014$ & B3 & $\begin{array}{l}\text { Ol kitapta böyle } \\
\text { yazılı }\end{array}$ & Mustafa KARA & $\begin{array}{c}\text { http://www.evrensel.net/yazi/70539/ol-kitapta-boyle- } \\
\text { yazili }\end{array}$ & 0 \\
\hline 9 & Ev & 04/08/2014 & B4 & $\begin{array}{l}\text { 'Sol' çetecilik mi, } \\
\text { devrimci } \\
\text { demokrasi mi? }\end{array}$ & Yusuf KARATAŞ & $\frac{\text { http://www.evrensel.net/yazi/71967/sol-cetecilik-mi- }}{\text { devrimci-demokrasi-mi }}$ & 1 \\
\hline 10 & Ev & 06/08/2014 & B4 & $\begin{array}{l}\text { Şengal'de ne } \\
\text { oldu? }\end{array}$ & Fehim IŞIK & http://www.evrensel.net/yazi/71984/sengalde-ne-oldu & 2 \\
\hline 11 & OG & $23 / 09 / 2014$ & D1 & $\begin{array}{l}\text { Ahmet Hakan'ın } \\
\text { yazısı Akdoğan'ın } \\
\text { itirafnamesi }\end{array}$ & Veysi SARISÖZEN & $\frac{\text { http://www.ozgur-gundem.com/yazi/119223/ahmet- }}{\text { hakanin-yazisi-akdoganin-itirafnamesi }}$ & 2 \\
\hline 12 & Ev & 29/09/2014 & D1 & $\begin{array}{l}\text { ID ya da alt } \\
\text { benlik }\end{array}$ & $\begin{array}{l}\text { Şebnem Korur } \\
\text { FiNCANCl }\end{array}$ & $\frac{\text { http://www.evrensel.net/yazi/72371/id-ya-da-alt- }}{\text { benlik }}$ & 1 \\
\hline 13 & Ev & 04/10/2014 & D2 & $\begin{array}{c}\text { Humus'ta } \\
\text { çocuklar ölürken } \\
\text { meleklerin } \\
\text { cinsiyetini } \\
\text { tartışmak } \\
\end{array}$ & Ayhan BíLGEN & $\begin{array}{l}\text { http://www.evrensel.net/yazi/72408/humusta- } \\
\text { cocuklar-olurken-meleklerin-cinsiyetini-tartismak }\end{array}$ & 0 \\
\hline 14 & Ev & $04 / 10 / 2014$ & D2 & $\begin{array}{l}\text { AKP, MHP ve } \\
\text { IşiD savaş } \\
\text { ortaklığı }\end{array}$ & Ender IMREK & $\begin{array}{c}\text { http://www.evrensel.net/yazi/72407/akp-mhp-ve-isid- } \\
\text { savas-ortakligi }\end{array}$ & 2 \\
\hline 15 & Ev & $05 / 10 / 2014$ & D2 & $\begin{array}{l}\text { 'Dayê dünya } \\
\text { xayine'! }\end{array}$ & Vedat ILBEYOĞLU & http://www.evrensel.net/yazi/72411/day-dunya-xayine & 2 \\
\hline 16 & Ev & $10 / 10 / 2014$ & D2 & $\begin{array}{l}\text { Kürt düşmanlığı, } \\
\text { IŞiD } \\
\text { propagandası }\end{array}$ & Esra ARSAN & $\frac{\text { http://www.evrensel.net/yazi/72448/kurt-dusmanligi- }}{\text { isid-propagandasi }}$ & 1 \\
\hline 17 & Ev & $10 / 10 / 2014$ & D2 & Uşak kime denir? & $\begin{array}{l}\text { Ahmet } \\
\text { YAŞAROĞLU }\end{array}$ & http://www.evrensel.net/yazi/72451/usak-kime-denir & 2 \\
\hline
\end{tabular}




\begin{tabular}{|c|c|c|c|c|c|c|c|}
\hline 18 & Ev & $12 / 10 / 2014$ & D2 & $\begin{array}{l}\text { Derin devlet, } \\
\text { büyük reis, çetesi } \\
\text { ve çetelesi }\end{array}$ & Mesut KARA & $\begin{array}{c}\text { http://www.evrensel.net/yazi/72461/derin-devlet- } \\
\text { buyuk-reis-cetesi-ve-cetelesi }\end{array}$ & 1 \\
\hline 19 & OG & $21 / 10 / 2014$ & D3 & $\begin{array}{l}\text { Negatif Barış, } \\
\text { Pozitif Barış }\end{array}$ & Kemal BÜLBÜL & $\frac{\text { http://www.ozgur-gundem.com/vazi/120899/negatif- }}{\text { baris-pozitif-baris }}$ & 1 \\
\hline 20 & Ev & $24 / 10 / 2014$ & D3 & $\begin{array}{l}\text { İdealleri de öyle } \\
\text { değil miymiş? }\end{array}$ & $\begin{array}{c}\text { Çağdaş } \\
\text { GÜNERBÜYÜK }\end{array}$ & $\frac{\text { http://www.evrensel.net/yazi/72555/idealleri-de-oyle- }}{\text { degil-miymis }}$ & 0 \\
\hline 21 & Ev & $24 / 10 / 2014$ & D3 & $\begin{array}{c}\text { Kötü haber: } \\
\text { Kürtler } \\
\text { kahraman } \\
\text { oluyor! } \\
\end{array}$ & Esra ARSAN & $\frac{\text { http://www.evrensel.net/yazi/72559/kotu-haber- }}{\text { kurtler-kahraman-oluyor }}$ & 1 \\
\hline 22 & Ev & $29 / 01 / 2014$ & D4 & $\begin{array}{l}\text { Türkiye'de bilim } \\
\text { ve bilim } \\
\text { politikaları (1) }\end{array}$ & İrfan AÇIKGÖZ & $\frac{\text { http://www.evrensel.net/yazi/73281/turkiyede-bilim- }}{\underline{\text { ve-bilim-politikalari-1 }}}$ & 0 \\
\hline 23 & Ev & $30 / 01 / 2015$ & D4 & $\begin{array}{c}\text { Değerler eğitimi: } \\
\text { Ruble, avro, } \\
\text { dolar lira, din, } \\
\text { iman }\end{array}$ & Adnan GÜMÜŞ & $\frac{\text { http://www.evrensel.net/yazi/73290/degerler-egitimi- }}{\text { ruble-avro-dolar-lira-din-iman }}$ & 0 \\
\hline 24 & OG & $02 / 02 / 2015$ & D4 & Alametler belirdi & Ragıp ZARAKOLU & $\begin{array}{c}\text { http://www.ozgur- } \\
\text { gundem.com//yazi/125150/alametler-belirdi }\end{array}$ & 1 \\
\hline 25 & Ev & $03 / 02 / 2015$ & D4 & $\begin{array}{l}\text { Üç strateji, üç } \\
\text { model: İşçilerin } \\
\text { dış politikası } \\
\text { nedir? }\end{array}$ & M. Sinan BIRDAL & $\frac{\text { http://www.evrensel.net/yazi/73317/uc-strateji-uc- }}{\text { model-iscilerin-dis-politikasi-nedir }}$ & 2 \\
\hline 26 & Ev & 05/02/2015 & D4 & $\begin{array}{l}\text { İç Güvenlik } \\
\text { Yasası }\end{array}$ & Kamil Tekin SÜREK & http://www.evrensel.net/yazi/73332/ic-guvenlik-yasasi & 0 \\
\hline 27 & Ev & $23 / 02 / 2015$ & A1 & $\begin{array}{l}\text { Süleyman Şah ve } \\
\text { Çin füzeleri } \\
\text { hamleleri }\end{array}$ & Mustafa YALÇINER & $\begin{array}{c}\text { http://www.evrensel.net/yazi/73462/suleyman-sah-ve- } \\
\text { cin-fuzeleri-hamleleri }\end{array}$ & 2 \\
\hline 28 & Ev & $25 / 02 / 2015$ & A1 & $\begin{array}{l}\text { Bir başka açıdan } \\
\text { 'Şah Fırat } \\
\text { operasyonu' }\end{array}$ & Fehim IŞIK & $\frac{\text { http://www.evrensel.net/yazi/73474/bir-baska-acidan- }}{\text { sah-firat-operasyonu }}$ & 2 \\
\hline 29 & Ev & $27 / 02 / 2015$ & $\mathrm{~A} 1$ & $\begin{array}{c}\text { Bugünün 70. yılı: } \\
\text { Yalta ve Postdam } \\
\text { Konferansı NATO } \\
\text { ve atom } \\
\text { bombaları }\end{array}$ & Adnan GÜMÜŞ & $\begin{array}{l}\text { http://www.evrensel.net/yazi/73490/bugunun-70-yili- } \\
\text { yalta-ve-postdam-konferansi-nato-ve-atom-bombalari }\end{array}$ & 0 \\
\hline 30 & Ev & $28 / 02 / 2015$ & A1 & $\begin{array}{l}\text { Yanıtı içinde } \\
\text { soru: Sen kime } \\
\text { bağ|ısın? }\end{array}$ & İhsan ÇARALAN & $\frac{\text { http://www.evrensel.net/yazi/73497/yaniti-icinde- }}{\text { soru-sen-kime-baglisin }}$ & 0 \\
\hline 31 & OG & 02/03/2015 & $\mathrm{A} 1$ & $\begin{array}{l}\text { Empati kuralım } \\
\text { empatik olalım }\end{array}$ & Ender ÖNDEŞ & $\begin{array}{c}\text { http://www.ozgur-gundem.com/vazi/127186/empati- } \\
\text { kuralim-empatik-olalim }\end{array}$ & 0 \\
\hline 32 & OG & 02/03/2015 & A1 & $\begin{array}{l}\text { Yaşar Kemal ve } \\
\text { Abdullah Öcalan }\end{array}$ & Filiz KOÇALI & $\frac{\text { http://www.ozgur-gundem.com/vazi/127189/yasar- }}{\text { kemal-ve-abdullah-ocalan }}$ & 1 \\
\hline 33 & Ev & 03/03/2015 & A1 & $\begin{array}{c}\text { Bu kez } \\
\text { Süryani/Asuriler } \\
\text { soykırım tehdidi } \\
\text { altında }\end{array}$ & Ragıp ZARAKOLU & $\frac{\text { http://www.evrensel.net/yazi/73515/bu-kez-suryani- }}{\text { asuriler-soykirim-tehdidi-altinda }}$ & 1 \\
\hline 34 & OG & $16 / 06 / 2015$ & A2 & $\begin{array}{c}\text { İran ile Kürt } \\
\text { güçleri } \\
\text { arasındaki } \\
\text { gerginlik devam } \\
\text { ediyor } \\
\end{array}$ & Rahmi YAĞMUR & $\frac{\text { http://www.ozgur-gundem.com/yazi/133476/iran-ile- }}{\text { kurt-gucleri-arasindaki-gerginlik-devam-ediyor }}$ & 0 \\
\hline 35 & OG & $17 / 06 / 2015$ & A2 & $\begin{array}{l}\text { Yeni hükümet ve } \\
\text { çözüm süreci }\end{array}$ & Besê HOZAT & $\frac{\text { http://www.ozgur-gundem.com/vazi/133485/veni- }}{\text { hukumet-ve-cozum-sureci }}$ & 0 \\
\hline
\end{tabular}




\begin{tabular}{|c|c|c|c|c|c|c|c|}
\hline 36 & Ev & $17 / 06 / 2015$ & $\mathrm{~A} 2$ & $\begin{array}{l}\text { Erdoğan da dahil } \\
\text { IşiD'i tercih } \\
\text { edenlerin asıl } \\
\text { korkusu ne? }\end{array}$ & Fehim IŞIK & $\frac{\text { http://www.evrensel.net/yazi/74276/erdogan-da- }}{\text { dahil-isidi-tercih-edenlerin-asil-korkusu-ne }}$ & 2 \\
\hline 37 & Ev & $18 / 06 / 2015$ & $\mathrm{~A} 2$ & $\begin{array}{l}\text { Egemenlerin yüz } \\
\text { yıllık kabusu } \\
\text { gerçek oldu! }\end{array}$ & Ihsan ÇARALAN & $\frac{\text { http://www.evrensel.net/yazi/74286/egemenlerin-yuz-- }}{\text { yillik-kabusu-gercek-oldu }}$ & 2 \\
\hline 38 & OG & $22 / 06 / 2015$ & $\mathrm{~A} 2$ & $\begin{array}{c}\text { Sabah, Star, } \\
\text { Rudaw ve } \\
\text { Satılmış } \\
\text { Gazeteciler... }\end{array}$ & Baki GÜL & $\frac{\text { http://www.ozgur-gundem.com/yazi/133509/sabah- }}{\text { star-rudaw-ve-satilmis-gazeteciler }}$ & 0 \\
\hline 39 & Ev & $22 / 06 / 2015$ & A2 & $\begin{array}{c}\text { Ilk hedefimiz } \\
\text { Akdeniz'dir, ileri! }\end{array}$ & Yusuf KARATAŞ & $\begin{array}{c}\text { http://www.evrensel.net/yazi/75676/barista-ucuran- } \\
\text { ekonomi-savasta-ne-yapar }\end{array}$ & 2 \\
\hline 40 & Ev & $24 / 06 / 2015$ & A2 & $\begin{array}{l}\text { IŞiD'in beli } \\
\text { Rakka'da mı } \\
\text { kırılacak? }\end{array}$ & Fehim IŞIK & $\frac{\text { http://www.evrensel.net/yazi/74327/isidin-beli- }}{\text { rakkada-mi-kirilacak }}$ & 2 \\
\hline 41 & OG & $27 / 12 / 2015$ & A3 & $\begin{array}{l}\text { Hendekler neden } \\
\text { açıldı tekrar nasıl } \\
\text { kapanır? }\end{array}$ & Veysi SARISÖZEN & $\begin{array}{c}\text { http://www.ozgur- } \\
\text { gundem.com/vazi/134645/hendekler-neden-acildi- } \\
\text { tekrar-nasil-kapanir }\end{array}$ & 0 \\
\hline 42 & Ev & $27 / 12 / 2015$ & A3 & $\begin{array}{l}\text { Çocuk olmak çok } \\
\text { zor }\end{array}$ & $\begin{array}{c}\text { Serdar M. } \\
\text { DEĞiRMENCIOĞLU }\end{array}$ & $\frac{\text { http://www.evrensel.net/yazi/75618/cocuk-olmak-cok- }}{\underline{\text { zor }}}$ & 0 \\
\hline 43 & OG & $28 / 12 / 2015$ & A3 & $\begin{array}{l}\text { Tişrin'den } \\
\text { Cerablus'a }\end{array}$ & M. Ali ÇELEBi & $\begin{array}{c}\underline{h t t p: / / w w w . o z g u r-~} \\
\text { gundem.com/yazi/134652/tisrinden-cerablusa }\end{array}$ & 2 \\
\hline 44 & Ev & $28 / 12 / 2015$ & A3 & $\begin{array}{l}\text { Sirada Kandil'e } \\
\text { operasyon mu } \\
\text { var? }\end{array}$ & Yusuf KARATAŞ & $\frac{\text { http://www.evrensel.net/yazi/75623/sirada-kandile- }}{\text { operasyon-mu-var }}$ & 2 \\
\hline 45 & Ev & $30 / 12 / 2015$ & A3 & $\begin{array}{l}\text { Arap Birliği, } \\
\text { Fırat'ın batısı, } \\
\text { Başika... }\end{array}$ & Aydın ÇUBUKÇU & $\begin{array}{c}\text { http://www.evrensel.net/yazi/75642/arap-birligi- } \\
\text { firatin-batisi-basika }\end{array}$ & 2 \\
\hline 46 & Ev & $30 / 12 / 2015$ & A3 & $\begin{array}{l}\text { AKP'yi ABD'yle } \\
\text { korkutmak... }\end{array}$ & Fehim IŞIK & $\begin{array}{c}\text { http://www.evrensel.net/yazi/75639/akpyi-abdyle- } \\
\text { korkutmak }\end{array}$ & 2 \\
\hline 47 & Ev & $01 / 01 / 2016$ & A3 & $\begin{array}{l}\text { 2016: Kıyamete } \\
\text { bir yıl daha } \\
\text { yaklaşıldı } \\
\text { devrimler } \\
\text { yakındır } \\
\end{array}$ & Adnan GÜMÜŞ & $\frac{\text { http://www.evrensel.net/yazi/75654/2016-kiyamete- }}{\text { bir-yil-daha-yaklasildi-devrimler-yakindir }}$ & 0 \\
\hline 48 & Ev & $02 / 01 / 2016$ & A3 & $\begin{array}{c}\text { Gerçek } \\
\text { kameranın } \\
\text { konduğu yerde } \\
\text { başlıyor }\end{array}$ & Suncem KOÇER & $\frac{\text { http://www.evrensel.net/yazi/75664/gercek- }}{\text { kameranin-kondugu-yerde-basliyor }}$ & 0 \\
\hline 49 & Ev & 03/01/2016 & A3 & $\begin{array}{c}\text { Şeytan taşlama } \\
\text { meselesi }\end{array}$ & $\begin{array}{c}\text { Migirdiç } \\
\text { MARGOSYAN }\end{array}$ & $\begin{array}{c}\text { http://www.evrensel.net/yazi/75669/seytan-taslama- } \\
\text { meselesi }\end{array}$ & 0 \\
\hline 50 & Ev & 03/01/2016 & A3 & $\begin{array}{l}\text { iliş̧irilmiş } \\
\text { gazetecilik }\end{array}$ & Ceren SÖZERI & $\begin{array}{c}\frac{\text { http://www.evrensel.net/yazi/75671/ilistirilmis- }}{\text { gazetecilik }} \\
\end{array}$ & 0 \\
\hline 51 & Ev & 03/01/2016 & A3 & $\begin{array}{l}\text { Zaman daralıyor, } \\
\text { 'Gecikmiş tedavi' } \\
\text { tedavi olmaz! }\end{array}$ & Vedat ILBEYOĞLU & $\frac{\text { http://www.evrensel.net/yazi/75673/zaman-daraliyor- }}{\text { gecikmis-tedavi-tedavi-olmaz }}$ & 1 \\
\hline 52 & OG & 04/01/2016 & A3 & $\begin{array}{l}\text { Cizre, Sur, Silopi } \\
\text { ve barikatlarda } \\
\text { yükselen YPS }\end{array}$ & Baki GÜL & $\frac{\text { http://www.ozgur-gundem.com/vazi/134691/cizre-sur- }}{\text { silopi-ve-barikatlarda-yukselen-yps }}$ & 0 \\
\hline 53 & OG & 04/01/2016 & A3 & $\begin{array}{l}\text { Suriye ve } \\
\text { Cerablûs }\end{array}$ & M. Ali ÇELEBi & $\frac{\text { http://www.ozgur-gundem.com/vazi/134690/surive- }}{\text { ve-cerabl-s }}$ & 2 \\
\hline 54 & Ev & $04 / 01 / 2016$ & A3 & $\begin{array}{c}\text { Barışta uçuran } \\
\text { ekonomi savaşta } \\
\text { ne yapar }\end{array}$ & $\begin{array}{l}\text { Bülent } \\
\text { FALAKAOĞLU }\end{array}$ & $\frac{\text { http://www.evrensel.net/yazi/75676/barista-ucuran- }}{\text { ekonomi-savasta-ne-yapar }}$ & 1 \\
\hline
\end{tabular}




\begin{tabular}{|c|c|c|c|c|c|c|c|}
\hline 55 & Ev & 05/01/2016 & A3 & $\begin{array}{l}\text { Diyanetten rest: } \\
\text { Cemevlerine } \\
\text { ibadethane } \\
\text { statüsü } \\
\text { verilemez! }\end{array}$ & İhsan ÇARALAN & $\frac{\text { http://www.evrensel.net/yazi/75688/diyanetten-rest- }}{\text { cemevlerine-ibadethane-statusu-verilemez }}$ & 0 \\
\hline 56 & Ev & $06 / 01 / 2016$ & A3 & $\begin{array}{c}\text { Mezhep } \\
\text { çatışması üzerine } \\
\text { eleştirel bir } \\
\text { deneme-1 } \\
\end{array}$ & M. Sinan BIIRDAL & $\frac{\text { http://www.evrensel.net/yazi/75694/mezhep- }}{\underline{\text { catismasi-uzerine-elestirel-bir-deneme-1 }}}$ & 0 \\
\hline 57 & Ev & 06/01/2016 & A3 & $\begin{array}{l}\text { Mezhep savaşı } \\
\text { mı? }\end{array}$ & Aydın ÇUBUKÇU & $\frac{\underline{\text { http://www.evrensel.net/vazi/75696/mezhep-savasi- }}}{\underline{\mathrm{mi}}}$ & 0 \\
\hline 58 & Ev & $17 / 03 / 2016$ & A4 & $\begin{array}{l}\text { Teröre bağlanan } \\
\text { yönetim } \\
\text { politikası }\end{array}$ & A. Cihan SOYLU & $\frac{\text { http://www.evrensel.net/yazi/76222/terore-baglanan- }}{\text { yonetim-politikasi }}$ & 0 \\
\hline 59 & OG & $19 / 03 / 2016$ & A4 & $\begin{array}{l}\text { Hitler nasıl } \\
\text { Führer oldu? }\end{array}$ & Şaban IBA & $\frac{\text { http://ozgur-gundem.com/yazi/135165/hitler-nasil- }}{\text { fuhrer-oldu }}$ & 0 \\
\hline 60 & OG & $20 / 03 / 2016$ & A4 & $\begin{array}{c}\text { Öcalan } \\
\text { konuşursa... }\end{array}$ & Suat BOZKUŞ & 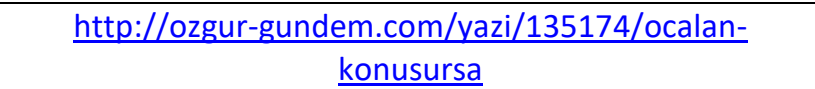 & 0 \\
\hline 61 & Ev & $21 / 03 / 2016$ & A4 & $\begin{array}{c}\text { Dokunulmazlıklar } \\
\text { mı, anayasa mı, } \\
\text { bombalar mı? }\end{array}$ & Mustafa YALÇINER & $\frac{\text { http://www.evrensel.net/yazi/76254/dokunulmazliklar- }}{\text { mi-anayasa-mi-bombalar-mi }}$ & 0 \\
\hline 62 & Ev & $23 / 03 / 2016$ & A4 & $\begin{array}{c}\text { İç ve dış politika } \\
\text { 'terörle } \\
\text { mücadele'ye } \\
\text { indirgenirse!.. }\end{array}$ & İhsan ÇARALAN & $\frac{\text { http://www.evrensel.net/yazi/76268/ic-ve-dis-politika- }}{\text { terorle-mucadeleye-indirgenirse }}$ & 0 \\
\hline 63 & $\mathrm{Ev}$ & $23 / 03 / 2016$ & A4 & $\begin{array}{l}\text { Rojava ve Kuzey } \\
\text { Suriye'de } \\
\text { federalizm }\end{array}$ & Fehim IŞIK & $\frac{\text { http://www.evrensel.net/yazi/76265/rojava-ve-kuzey- }}{\text { suriyede-federalizm }}$ & 2 \\
\hline 64 & Ev & $24 / 03 / 2016$ & A4 & $\begin{array}{l}\text { Teorik, siyasal ve } \\
\text { ekonomik } \\
\text { mücadele }\end{array}$ & Sinan ALÇIN & $\frac{\text { http://www.evrensel.net/yazi/76273/teorik-siyasal-ve- }}{\text { ekonomik-mucadele }}$ & 0 \\
\hline 65 & Ev & $26 / 03 / 2016$ & A4 & $\begin{array}{l}1 \text { Mayıs, Taksim, } \\
\text { dönem ve } \\
\text { sorumluluk... }\end{array}$ & Ender IMREK & $\frac{\mathrm{http}: / / \text { www.evrensel.net/yazi/76287/1-mayis-taksim- }}{\underline{\text { donem-ve-sorumluluk }}}$ & 0 \\
\hline
\end{tabular}

\section{Key:}

$\mathrm{Ev}=$ Evrensel $/ \mathrm{OG}=$ Özgür Gündem

$2=$ articles in which geopolitical code elements have a main role

$1=$ articles in which the main topic is not geopolitical but incidentally contain relevant geopolitical code information

$0=$ articles without geopolitical code information 


\section{Appendix 2: Full list of macropropositions}

\begin{tabular}{|c|c|c|c|c|c|c|}
\hline $\begin{array}{l}\text { Article } \\
\text { No. }\end{array}$ & Period & GC & $\begin{array}{l}\text { Macr. } \\
\text { No. }\end{array}$ & Geopolitical Macroproposition & Function & Code \\
\hline \multirow{2}{*}{1} & \multirow{2}{*}{$\mathrm{B}^{*}$} & \multirow{2}{*}{2} & 1 & $\begin{array}{c}\text { KDP (Barzani) is against Rojava, along with Israel, US and } \\
\text { Turkey }\end{array}$ & $\mathrm{D}$ & E-KRG \\
\hline & & & 2 & Disputes between Kurds should be avoided & $\mathrm{P}$ & Intern \\
\hline \multirow{2}{*}{2} & \multirow{2}{*}{$\mathrm{B}^{*}$} & \multirow{2}{*}{2} & 3 & $\begin{array}{l}\text { Turkey has allied itself with al-Qaeda and salafi groups against } \\
\text { al-Assad }\end{array}$ & $\mathrm{D}$ & E-TR \\
\hline & & & 4 & Turkey won't intervene in Rojava & $\mathrm{P}$ & TR \\
\hline \multirow{2}{*}{3} & \multirow{2}{*}{$\mathrm{B}^{*}$} & \multirow{2}{*}{2} & 5 & Russia as possible partner, but it's not a sincere position & $\mathrm{D}$ & 3rd-RUS \\
\hline & & & 6 & Turkey and Saudi Arabia supporting radical opposition in Syria & $\mathrm{D}$ & E-TR \\
\hline \multirow{4}{*}{4} & \multirow{4}{*}{$\mathrm{B}^{*}$} & \multirow{4}{*}{2} & 7 & Turkey is against Rojava Revolution and Kurdish refugees & $\mathrm{D}$ & E-TR \\
\hline & & & 8 & Borders should be opened and assistance provided & $\mathrm{P}$ & TR \\
\hline & & & 9 & Rojava revolution is a feminist revolution & $\mathrm{L}$ & Postmat \\
\hline & & & 10 & Rojava as a plural space with no sectarianism & $\mathrm{L}$ & Postmat \\
\hline 5 & $\mathrm{~B}^{*}$ & 1 & 11 & $\begin{array}{l}\text { Kurdish opposition parties of Rojava are not in the same } \\
\text { direction as PYD }\end{array}$ & $\mathrm{D}$ & $\mathrm{A}-\mathrm{OKu}$ \\
\hline 6 & $\mathrm{~B}^{*}$ & 2 & 12 & $\begin{array}{l}\text { Turkish government involved in dark maneuvers with al-Qaeda } \\
\text { and other radical islamist groups in Syria }\end{array}$ & $\mathrm{D}$ & E-TR \\
\hline \multirow{3}{*}{7} & \multirow{3}{*}{ B3 } & \multirow{3}{*}{2} & 13 & $\begin{array}{c}\text { Ongoing revolutionary struggle in Rojava is unavoidable and } \\
\text { presents brighter future for Kurds }\end{array}$ & $\mathrm{L}$ & Postmat \\
\hline & & & 14 & $\begin{array}{c}\text { Global powers (imperialists, Geneva, colonialists, etc) + Turkish } \\
\text { government + Al-Qaeda (and regional jihadist groups) + Gülen } \\
\text { are against Rojava }\end{array}$ & $\mathrm{D}$ & E-TR \\
\hline & & & 15 & $\begin{array}{l}\text { Union of different peoples strengthens revolutions (e.g. } \\
\text { communists, arabs, sunni, alevis, syriacs, circassians, etc) }\end{array}$ & $\mathrm{L}$ & Postmat \\
\hline 9 & B4 & 1 & 16 & Rojava is the only democratic hope for region & $\mathrm{L}$ & Postmat \\
\hline 10 & B4 & 2 & 17 & $\begin{array}{l}\text { KRG could have better protected Sinjar from Daesh; maybe is not } \\
\text { an ally }\end{array}$ & $\mathrm{D}$ & 3rd-KRG \\
\hline \multirow[b]{2}{*}{11} & \multirow[b]{2}{*}{ D1 } & \multirow[b]{2}{*}{2} & 18 & $\begin{array}{l}\text { Rojava success is connected with chances of success of solution } \\
\text { process in Turkey }\end{array}$ & $\mathrm{L}$ & Mat \\
\hline & & & 19 & $\begin{array}{c}\text { Government is lying about Kobane and Turkey is an ally of } \\
\text { Daesh against the Kurds. }\end{array}$ & $\mathrm{D}$ & E-TR \\
\hline 12 & D1 & 1 & 20 & Turkey allied with Daesh against Kurds (war by intermediation) & $\mathrm{D}$ & E-TR \\
\hline \multirow{2}{*}{14} & \multirow{2}{*}{ D2 } & \multirow[b]{2}{*}{2} & 21 & AKP and MHP allied with ISIS against Kurds & $\mathrm{D}$ & E-TR \\
\hline & & & 22 & $\begin{array}{c}\text { Measures taken by Turkey (resolution + proposal of buffer zone) } \\
\text { are not helpful for Kurds, just a scheme }\end{array}$ & $\mathrm{D}$ & E-TR \\
\hline \multirow{3}{*}{15} & \multirow{3}{*}{ D2 } & \multirow{3}{*}{2} & 23 & $\begin{array}{l}\text { Last developments and declarations by Turkish government are } \\
\text { not sincere: Turkey wants Kobane defeated }\end{array}$ & $\mathrm{D}$ & E-TR \\
\hline & & & 24 & International coalition also ineffective and hypocrital & $\mathrm{D}$ & 3rd-W \\
\hline & & & 25 & $\begin{array}{c}\text { Coraugeous brothers and sisters, their ideals will remain in any } \\
\text { case }\end{array}$ & $\mathrm{L}$ & Postmat \\
\hline 16 & D2 & 1 & 26 & $\begin{array}{l}\text { Turkish Media + Police + Government against Kurds; Media is } \\
\text { indifferent to Kobane and promotes hatred }\end{array}$ & $\mathrm{D}$ & E-TR \\
\hline
\end{tabular}




\begin{tabular}{|c|c|c|c|c|c|c|}
\hline \multirow{5}{*}{17} & \multirow{5}{*}{ D2 } & \multirow{5}{*}{2} & 27 & $\begin{array}{l}\text { Turkey and the US don't have different positions toward the } \\
\text { Kurds, just tactical differences (US not an ally of Kurds) }\end{array}$ & $\mathrm{D}$ & 3rd-US \\
\hline & & & 28 & Turkey wants Kurds' defeat & $\mathrm{D}$ & E-TR \\
\hline & & & 29 & Kurds should not rely on Americans and imperialism. & $\mathrm{P}$ & Intern \\
\hline & & & 30 & Need to resist using brotherhood, solidarity and hope & $\mathrm{P}$ & Intern \\
\hline & & & 31 & All progressive forces in region should join resistance & $\mathrm{P}$ & Intern \\
\hline 18 & D2 & 1 & 32 & Turkey is using Hizbollah in contra tactics, as in the 1990s & $\mathrm{D}$ & E-TR \\
\hline \multirow{2}{*}{19} & \multirow{2}{*}{ D3 } & \multirow{2}{*}{1} & 33 & Turkey should recognize Rojava cantons & $\mathrm{P}$ & TR \\
\hline & & & 34 & Kurdish political project within Turkey & $\mathrm{P}$ & Intern \\
\hline \multirow{3}{*}{21} & \multirow{3}{*}{ D3 } & \multirow{3}{*}{1} & 35 & $\begin{array}{l}\text { Mass Turkish media conducting a campaign against Kurds, while } \\
\text { international media reflects epic resistance in Kobane }\end{array}$ & $\mathrm{D}$ & E-TR \\
\hline & & & 36 & Last measures announced by Turkey to "help" Kobane are a lie & $\mathrm{D}$ & E-TR \\
\hline & & & 37 & There is no alliance or link of Kurds with the US & $\mathrm{D}$ & 3rd-US \\
\hline 24 & D4 & 1 & 38 & Greece as a model to follow for Turkey’s Kurds. & $\mathrm{P}$ & Intern \\
\hline \multirow{3}{*}{25} & \multirow{3}{*}{ D4 } & \multirow{3}{*}{2} & 39 & There is no alliance of Kurds with US & $\mathrm{D}$ & 3rd-US \\
\hline & & & 40 & $\begin{array}{l}\text { Freedom, equality and labor protection as key points of Kurdish } \\
\text { model }\end{array}$ & $\mathrm{L}$ & Mat \\
\hline & & & 41 & Kurds as only truly democratic actor in the Middle East & $\mathrm{L}$ & Postmat \\
\hline 27 & A1 & 2 & 42 & $\begin{array}{l}\text { Turkey is moving away from Western bloc and developing more } \\
\text { relations with Russia and China. }\end{array}$ & $\mathrm{D}$ & E-TR \\
\hline \multirow{4}{*}{28} & \multirow{4}{*}{ A1 } & \multirow{4}{*}{2} & 43 & $\begin{array}{c}\text { Turkey supported ISIS but after Kobane the relationship is } \\
\text { deteriorating }\end{array}$ & $\mathrm{D}$ & E-TR \\
\hline & & & 44 & $\begin{array}{c}\text { Turkey and YPG collaborated tactically in Suleyman Shah } \\
\text { Turbesi, both benefited }\end{array}$ & $\mathrm{D}$ & E-TR \\
\hline & & & 45 & $\begin{array}{l}\text { Despite past events, it is important for Kurds to offer cooperation } \\
\text { for peace in the region and solution process in Turkey }\end{array}$ & $\mathrm{P}$ & Intern \\
\hline & & & 46 & Kurds as a force of stability and peace in the region & $\mathrm{L}$ & Mat \\
\hline \multirow[b]{2}{*}{32} & \multirow{2}{*}{ A1 } & \multirow{2}{*}{1} & 47 & Turkey is becoming isolated in NATO & $\mathrm{D}$ & E-TR \\
\hline & & & 48 & Responsible behavior of Kurdish movement ensures stability & $\mathrm{L}$ & Mat \\
\hline 33 & A1 & 1 & 49 & $\begin{array}{l}\text { Kurds defend and support other ethnicities and diversity in } \\
\text { region, all are part of the same strugggle }\end{array}$ & $\mathrm{L}$ & Postmat \\
\hline 36 & $\mathrm{~A} 2$ & 2 & 50 & Turkish government prefers Daesh rather than people's freedom & $\mathrm{D}$ & E-TR \\
\hline 37 & $\mathrm{~A} 2$ & 2 & 51 & $\begin{array}{l}\text { Criticism and defamation after Kurds take Tel Abyad shows how } \\
\text { Turkey is against Kurdish autonomy in Syria. }\end{array}$ & $\mathrm{D}$ & E-TR \\
\hline \multirow{3}{*}{39} & \multirow{3}{*}{$\mathrm{A} 2$} & \multirow{3}{*}{2} & 52 & $\begin{array}{l}\text { AKP's distress with Kurdish advancement shows link with } \\
\text { Daesh }\end{array}$ & $\mathrm{D}$ & E-TR \\
\hline & & & 53 & Kurds are fighting along with Turkmen and Arabs & $\mathrm{D}$ & A-Ethn \\
\hline & & & 54 & $\begin{array}{l}\text { Current fight is between sectarianism and oppression versus } \\
\text { plurality and democracy }\end{array}$ & $\mathrm{L}$ & Postmat \\
\hline \multirow{3}{*}{40} & \multirow{3}{*}{ A2 } & \multirow{3}{*}{2} & 55 & Western powers have done too little & $\mathrm{D}$ & 3rd-W \\
\hline & & & 56 & After Tel Abyad, Kurds now can attack Raqqa & $\mathrm{P}$ & Intern \\
\hline & & & 57 & Kobane as a decisive point in fight against Daesh & $\mathrm{L}$ & Mat \\
\hline
\end{tabular}




\begin{tabular}{|c|c|c|c|c|c|c|}
\hline 43 & A3 & 2 & 58 & $\begin{array}{c}\text { SDF and YPG will conquer Manjib-Jarabulus line and finally } \\
\text { defeat Daesh in Raqqa }\end{array}$ & $\mathrm{P}$ & Intern \\
\hline 44 & A3 & 2 & 59 & $\begin{array}{c}\text { Turkey and KRG, in compliance with US, have interest in } \\
\text { debilitating PKK-PYD }\end{array}$ & $\mathrm{D}$ & E-TR \\
\hline \multirow[b]{2}{*}{45} & \multirow[b]{2}{*}{ A3 } & \multirow[b]{2}{*}{2} & 60 & Move west of Euphrates should continue & $\mathrm{P}$ & Intern \\
\hline & & & 61 & $\begin{array}{l}\text { Kurds have the support of SDF and US to move West of } \\
\text { Euphrates }\end{array}$ & $\mathrm{D}$ & A-OMA \\
\hline 46 & $\mathrm{~A} 3$ & 2 & 62 & No project for independent Great Kurdistan & $\mathrm{P}$ & Intern \\
\hline 51 & A3 & 1 & 63 & West is indifferent to Kurds' suffering & $\mathrm{D}$ & $3 \mathrm{rd}-\mathrm{W}$ \\
\hline \multirow{4}{*}{53} & \multirow{4}{*}{ A3 } & \multirow{4}{*}{2} & 64 & Western indifference in Geneva talks & $\mathrm{D}$ & $3 \mathrm{rd}-\mathrm{W}$ \\
\hline & & & 65 & Turkey, Qatar and Saudi Arabia arming and supporting jihadists & $\mathrm{D}$ & E-TR \\
\hline & & & 66 & If Jarabulus operation is successful, Daesh will fall & $\mathrm{P}$ & Intern \\
\hline & & & 67 & Jarabulus operation is a fight between peace and barbarism & $\mathrm{L}$ & Mat \\
\hline 54 & A3 & 1 & 68 & $\begin{array}{l}\text { Turkey against unifications of cantons because of political but } \\
\text { also economic reasons. }\end{array}$ & $\mathrm{D}$ & E-TR \\
\hline \multirow{2}{*}{63} & \multirow{2}{*}{ A4 } & \multirow{2}{*}{2} & 69 & $\begin{array}{c}\text { Change of name from Western Kurdistan to Northern Syria in } \\
\text { order to be more inclusive. }\end{array}$ & $\mathrm{L}$ & Postmat \\
\hline & & & 70 & Syrian opposition present in Geneva against federalism & $\mathrm{D}$ & E-FSA \\
\hline
\end{tabular}

\section{Key:}

Function: $\mathrm{D}=$ diagnostic. Macropropositions that present facts and definitions of a situation, which can also involve the identification of who or what have caused this situation.

$\mathrm{E}=$ enemies $/ \mathrm{A}=$ allies $/ 3 \mathrm{rd}=$ third parties

$\mathrm{KRG}=$ Kurdish Regional Government $/$ RUS $=$ Russia / US = United States $/ \mathrm{W}=$ the 'West' / TR = Turkey / FSA = Free Syrian Army / Ethn = other ethnic minorities / OKu = other Kurdish actors (different than the PYD-YPG) / OMA = other military actors in the Syrian war

Function: $\mathrm{P}=$ prognostic. Macropropositions that present recommendations about what should be done to improve the situation or predictions about the future.

TR = Turkey as addresse (Turkey should/will do something)

Intern = internally directed messages (Kurds should/will do something)

Function: L = legitimatory. Macropropositions that present self-representing statements of the collectivity to which the speaker identifies (in this case, Kurds)

Postmat $=$ post-materialistic arguments/values (emphasizing morally-based non-material goals such as self-expression, autonomy, freedom of speech, gender equality, or environmentalism). Mat = materialistic arguments/values (emphasizing the fulfillment of material needs, such as security, sustenance and shelter). 